\title{
An Empirical Study on Size and Age Effects in Korean Equity Funds: Focusing on the Issue of Neglected Funds
}

\author{
Dong-Soon Kim*, Professor, Chuang-Ang University Business School \\ Kyoung-Han Lee, Executive Managing Director, Hana Financial Investment
}

Hyun-Do Kim, Ph.D. Candidate, KAIST

\begin{abstract}
$\langle$ Abstract $\rangle$
In this study, we examine the effects of fund size and age on performance in the context of Korean equity funds. The Korean market has a large number of funds, with the funds being characterized by a small size and short life. We divided the sample into five sub-groups by size and used the market-adjusted return model, CAPM, and the Carhart four-factor model to measure risk-adjusted performance. We divided the study period (from 2006 to 2015) into 1st- and 2nd- half sub-periods beginning in 2010, because of the changes in the market environment at that time. We found the following empirical results: Only small funds have a significantly positive size effect; by contrast, the effect is negative in large funds. The age and expense ratio of funds have a negative effect on performance, which is aggravated in the case of small funds. In particular, sales fees have a negative effect, which indicates that sales channels' services fail to cover investors' costs. We observed that the size effect takes on a quadratic function, as the optimal size became strikingly lower in the 2nd half. For funds investing in growth stocks, the liquidity hypothesis was supported in the 2nd half. The cash holding ratio does not have a significant effect, which is inconsistent with the results of previous studies. Despite the negative age effect, older funds of larger size had better performance in the 1st half, while older and smaller funds had inferior performance. Finally, we can define small funds that are over 4 to 6 years old as neglected funds.
\end{abstract}

Keywords: Neglected Funds; Size Effect; Age Effect; Liquidity Hypothesis; Expense Ratio JEL Classification: G1 G2 N2

\footnotetext{
* Corresponding Author. Address: Chuang-Ang University Business School, 84, Heukseok-ro, Dongjak-gu, Seoul, Korea 06974; E-mail: dkim@cau.ac.kr; Tel: +82-2-820-5570;

Fax: +82-2-815-7001
}

Received: October 31, 2018; Revised: April 11, 2019 \& June 24, 2019; Accepted: June 27, 2019 


\title{
한국 주식형 펀드의 규모효과와 연령효과에 관한 연구: 소외펀드 문제를 중심으로
}

\author{
김 동 순 (중앙대학교 교수)* \\ 이 경 한 (하나금융투자 전무) \\ 김 현 도 (KAIST 박사과정)
}

\begin{abstract}
한국은 선진국에 비해 펀드수가 많고 규모는 작으며 수명도 짧다. 2006년부터 2015년까지 국내 공모 주식형 펀드 1,040 개를 표본으로 자산규모 기준 5 분위의 그룹으로 나누어 시장조정수익률, CAPM 및 Carhart의 4요인 모형에 따른 위험조정 성과의 패널분석을 수행하였다. 자산규모에 따라 소규모펀드와 중대형펀드 그룹으로 나누고 2009년 말을 기준으로 전, 후반기로 나누어 특징 변화도 분석하였다. 주요 실증분석의 결과로서, 첫째 기존연구에서 양 $(+)$ 의 관계로 나타났던 규모효과는 중대형펀드에서 음(-)의 결과로 반전되었는데 이는 후반기 중대형펀드에서 나타난 강한 음의 규모효과에 기인한다. 둘째, 펀드 연령과 비용부담률은 성과에 대하여 음(-)의 효과가 있었고 소규모펀드에서는 이런 현상이 심화되고 있다. 특히 운용보수와 달리 판매보수는 성과에 음(-)의 효과를 나타냈다. 셋째, 펀드의 규모효과는 이차함수의 형태였으며 펀드의 최적규모는 전반기를 다룬 이전 연구결과들에 비해 크게 낮아졌다. 넷째, 펀드 규모가 커지면 암묵적 비용인 시장충격 비용 등으로 성과에 불리하다는 유동성 가설은 후반기 성장주에 투자하는 중대형펀드의 경우 지지되었다. 다섯째, 현금보유 비중은 전체 기간에서 모형에 관계없이 유의하지 않아 최근 일부 연구의 결과와는 대조를 보였다. 여섯째, 오래된 소규모펀드는 성과에서 불리하였고, 그 연령 기준은 약 4 6년 이상이어서, 이를 소외펀드라고 정의할 수 있다.
\end{abstract}

핵심 단어 : 소외펀드, 규모효과, 연령효과, 유동성가설, 총비용부담률

JEL 분류기호: G1 G2 N2

* 연락담당 저자. 주소: 서울특별시 동작구 흑석로 84 중앙대학교 경영학부, 06974;

E-mail: dkim@cau.ac.kr; Tel: 02-820-5570; Fax: 02-815-7001 


\section{1. 서론}

국내 펀드시장은 선진국 시장에 비해 펀드 수가 많고 그 규모는 작으며 펀드의 존속기간도 짧은 특징을 가지고 있다. 이에 따라 금융당국이 규모가 일정 수준 이하인 펀드들의 임의 해지를 독려하고 있고, 국내 펀드산업의 실무관행도 규모가 작고 오래된 펀드에 대하여는 환매를 권유하고 있음은 주지의 사실이다. 이러한 국내펀드의 소규모, 단기 수명의 특성으로 인하여 소외되고 있는 펀드들도 많을 것으로 추정된다.

국내 펀드산업은 1997년 외환위기 이후 폭발적인 성장을 지속하여 왔으나 글로벌금융위기를 넘긴 2009년부터는 주식시장의 장기간 침체기가 시작되면서 주식형 펀드는 침체되고 채권형 펀드나 단기금융, 부동산 펀드 및 기타 특별자산 펀드가 상대적인 강세를 보이고 있다. 금융투자 협회의 자료(freesis.kofia.or.kr)에 따르면 투자 일임형을 제외한 주식형 펀드(국내외, 공사모 전체기준) 설정 원금은 2001년 말 6.92조 원에서 2008년 말 140.2조 원까지 급증하였으나 2016년 말 73.69조 원으로 정점 대비 거의 절반 수준 가까이 하락하고 있다.

〈표 1〉 주요국의 펀드 규모 및 펀드 수

이 표는 주요 40개국의 공사모 전체 펀드규모를 2016년 6월말 기준 순자산 순서로 배열하였음(ICI, Statistics Worldwide Market, 2Q, 2016).

단위: 미 백만 달러(in million U.S. dollar)

\begin{tabular}{|c|c|c|c|c|c|c|c|}
\hline \multirow[b]{2}{*}{ 국가 } & \multicolumn{4}{|c|}{ 전체 } & \multicolumn{3}{|c|}{ 주식형 } \\
\hline & 순자산 & 펀드 수 & $\begin{array}{l}\text { 펀드당 } \\
\text { 순자산 }\end{array}$ & $\begin{array}{c}\text { 미국대비 } \\
\text { 펀드당 } \\
\text { 순자산비율 }\end{array}$ & 순자산 & 펀드 수 & $\begin{array}{l}\text { 펀드당 } \\
\text { 순자산 }\end{array}$ \\
\hline United States & $19,923,184$ & 11,220 & 1,776 & $100 \%$ & $10,098,231$ & 6,248 & 1,616 \\
\hline Luxembourg & $3,843,406$ & 14,208 & 271 & $15 \%$ & $1,119,389$ & 3,787 & 296 \\
\hline Ireland & $2,128,143$ & 6,266 & 340 & $19 \%$ & 522,990 & n.a. & n.a. \\
\hline Germany & $2,003,612$ & 5,938 & 337 & $19 \%$ & 270,097 & 775 & 349 \\
\hline France & $1,866,100$ & 11,051 & 169 & $10 \%$ & 306,820 & 1,811 & 169 \\
\hline Australia & $1,597,258$ & n.a. & n.a. & n.a. & 628,806 & n.a. & n.a. \\
\hline United Kingdom & $1,522,253$ & 2,915 & 522 & $29 \%$ & 673,281 & 1,115 & 604 \\
\hline Brazil & $1,505,170$ & 14,615 & 103 & $6 \%$ & 60,092 & 1,865 & 32 \\
\hline Japan & $1,475,209$ & 10,345 & 143 & $8 \%$ & $1,326,109$ & 9,685 & 137 \\
\hline Canada & $1,301,847$ & 3,907 & 333 & $19 \%$ & 321,191 & 1,718 & 187 \\
\hline China & $1,154,330$ & 2,909 & 397 & $22 \%$ & 100,101 & 615 & 163 \\
\hline Netherlands & 781,512 & 1,030 & 759 & $43 \%$ & 289,388 & 369 & 784 \\
\hline Switzerland & 505,020 & 906 & 557 & $31 \%$ & 151,878 & 398 & 382 \\
\hline Korea, Rep. of & 393,589 & 13,194 & 30 & $2 \%$ & 61,093 & 1,938 & 32 \\
\hline Sweden & 305,744 & 570 & 536 & $30 \%$ & 178,193 & 319 & 559 \\
\hline Spain & 276,642 & 2,290 & 121 & $7 \%$ & 42,375 & 769 & 55 \\
\hline Italy & 257,934 & 968 & 266 & $15 \%$ & 20,349 & 108 & 188 \\
\hline Austria & 187,060 & 2,054 & 91 & $5 \%$ & 24,509 & 346 & 71 \\
\hline India & 178,483 & 870 & 205 & $12 \%$ & 53,782 & 317 & 170 \\
\hline South Africa & 157,222 & 1,817 & 87 & $5 \%$ & 36,651 & 401 & 91 \\
\hline
\end{tabular}


An Empirical Study on Size and Age Effects in Korean Equity Funds

〈표 1〉 주요국의 펀드 규모 및 펀드 수(계속)

\begin{tabular}{|c|c|c|c|c|c|c|c|}
\hline \multirow[b]{2}{*}{ 국가 } & \multicolumn{4}{|c|}{ 전체 } & \multicolumn{3}{|c|}{ 주식형 } \\
\hline & 순자산 & 펀드 수 & $\begin{array}{l}\text { 펀드당 } \\
\text { 순자산 }\end{array}$ & $\begin{array}{c}\text { 미국대비 } \\
\text { 펀드당 } \\
\text { 순자산비율 }\end{array}$ & 순자산 & 펀드 수 & $\begin{array}{l}\text { 펀드당 } \\
\text { 순자산 }\end{array}$ \\
\hline Belgium & 133,989 & 1,297 & 103 & $6 \%$ & 29,700 & 304 & 98 \\
\hline Denmark & 118,971 & 585 & 203 & $11 \%$ & 46,716 & 294 & 159 \\
\hline Mexico & 112,125 & 571 & 196 & $11 \%$ & 10,905 & 145 & 75 \\
\hline Norway & 109,576 & 691 & 159 & $9 \%$ & 50,210 & 396 & 127 \\
\hline Finland & 107,891 & 455 & 237 & $13 \%$ & 37,445 & 229 & 164 \\
\hline Taiwan & 68,880 & 699 & 99 & $6 \%$ & 15,748 & 346 & 46 \\
\hline New Zealand & 46,360 & 586 & 79 & $4 \%$ & 5,616 & 178 & 32 \\
\hline Liechtenstein & 45,598 & 1,302 & 35 & $2 \%$ & 8,940 & 329 & 27 \\
\hline Chile & 42,480 & 2,452 & 17 & $1 \%$ & 1,926 & 573 & 3 \\
\hline Poland & 32,397 & 508 & 64 & $4 \%$ & 6,139 & 186 & 33 \\
\hline Portugal & 23,998 & 420 & 57 & $3 \%$ & 1,035 & 48 & 22 \\
\hline Hungary & 17,637 & 452 & 39 & $2 \%$ & 914 & 82 & 11 \\
\hline Argentina & 16,512 & 366 & 45 & $3 \%$ & 510 & 50 & 10 \\
\hline Turkey & - 13,729 & 390 & 35 & $2 \%$ & 443 & 63 & 7 \\
\hline Czech Republic & 9,265 & 148 & 63 & $4 \%$ & 1,202 & 24 & 50 \\
\hline Trinidad \& Tobago & 6,814 & 44 & 155 & $9 \%$ & 42 & 11 & 4 \\
\hline Slovakia & 6,205 & 89 & 70 & $4 \%$ & 374 & 9 & 42 \\
\hline Philippines & 5,357 & 57 & 94 & $5 \%$ & 2,128 & 18 & 118 \\
\hline Romania & 5,172 & 76 & 68 & $4 \%$ & 75 & 15 & 5 \\
\hline Greece & 4,611 & 159 & 29 & $2 \%$ & 1,049 & 62 & 17 \\
\hline
\end{tabular}

한편, 2016년 6월 말 현재 국내 펀드 수는 공모 및 사모 합계 13,194개로, 국내 펀드보다 약 50 배 수준의 펀드 순자산 총액을 가진 미국의 11,220 개 보다 많으며 그러나 펀드당 평균 순자산은 29.8 백만 달러로 미국의 $1,775.7$ 백만 달러에 비해 현저히 작은 규모로서 세계 최하위권 이다(<표 1> 미국 ICI, 2016 2Q자료).

글로벌금융위기 이후 주식형 펀드 시장에는 또 다른 중요한 변화가 있었다. 금융당국은 2008년 체감식 판매보수제 도입에 이어 2009년 신규펀드 판매보수 및 판매수수료 한도 인하 등 펀드비용 절감을 위한 조치들을 연이어 발표하였다. 그리고 우리나라에 만연한 소규모펀드가 펀드의 운용효율을 떨어뜨리고 있다는 여론에 따라 금융위원회는 2010년 6월 자본시장법 시행령을 개정하여 50억 원 미만의 소규모펀드, 소위 '자투리펀드'에 대하여 투자자 보호의 관점에서 개선을 독려하였고 이후 일련의 관련 후속조치들을 발표하였다. 즉, 한국의 주식형 펀드 산업은 글로벌금융위기 이후인 2009년 말을 기준으로 증시 패턴의 변화와 함께 여러 주요한 조치들이 함께 나와 매우 특징적인 변화의 시기를 맞이하였다. 따라서 이 시기를 전후하여 어떤 변화가 있었는지 새로운 분석이 필요하다고 할 수 있다. 그리고 외국과는 달리, 펀드연령이 오래되고 규모가 작은 펀드가 성과에서 불리하고, 이에 따라 소외되고 환매가 권유되는 현상에 대해서도 분석이 이루어져야 할 것이다. 
한국증권학회지 제48권 6호 (2019)

또한 2007년부터 활성화되기 시작한 클래스펀드로 인하여 펀드성과 분석을 할 때 펀드평가사 에서 제공하는 펀드비용(판매보수)과 수익률을 그대로 쓰는 것은 문제가 있어 수정이 필요하고 클래스펀드의 규모도 완전히 파악하여야 하기 때문에 본 연구는 이러한 점에 유의해서 분석을 시도하였다.

논문의 구성은 제 2 장에서 관련 주제에 대한 국내외 선행연구들을 소개하고 제 3 장에서는 연구방법론으로 연구자료와 변수 정의 및 연구모형을 제시한다. 제 4장의 실증분석 결과에서는 패널분석 결과와 펀드의 최적규모, 유동성가설 검증, 펀드의 연령효과와 소외펀드 정의 및 소외펀드의 개선방안에 대해 기술한다. 마지막 제 5 장 결론에서는 연구의 요약과 국내 주식형 펀드산업의 발전방향을 제시한다.

\section{2. 펀드의 규모 및 연령효과 관련 선행연구}

\section{1 국내 펀드산업의 특성}

국내 펀드의 경우 규모가 작고 펀드 수는 많으며 펀드연령이 짧은 것이 뚜렷한 특징이다. 이와 함께 독특한 펀드비용 구조로 인하여 소외펀드가 발생할 여지가 많은 것도 국내 펀드산업의 특징이자 문제점이다.

펀드비용은 일반적으로 펀드 포트폴리오의 매매차원에서 이루어지는 거래비용으로 대표되는 암묵적 비용과, 판매수수료, 판매보수, 운용보수, 수탁보수 등 설정 시 투자설명서나 약관에 명기되는 명시적 비용이 있는데, 그 중 논란의 여지가 있는 것은 판매보수이다. Cho and $\operatorname{Shin}(2012)$ 은 펀드의 주요 판매 창구인 국내 증권사들이 펀드 판매라는 일종의 중개행위를 하면서 일회성의 판매수수료가 아닌 지속적인 판매보수를 받는 것은 독특한 제도라고 지적하고 있으며, Won and Hahn(2011)은 이러한 판매보수가 연간 펀드에서 부담하는 고정비용 중 상당부분(약 $65 \%$ )을 차지하고 있음을 밝히고 있다. 주요 선진국은 운용보수가 아닌 이러한 비운용보수의 경우 대부분 연간 펀드비용의 $10 \%$ 내외 수준이며 ' $12 \mathrm{~b}-1$ '의 형태로 판매보수를 일부 허용하고 있는 미국의 경우에도 약 $45 \%$ 를 넘지 않고 있다.

이러한 펀드의 판매보수는 국내 펀드의 단기화, 소형화 현상을 부추기고 있다는 점에서 문제가 되고 있다. 외국의 펀드는 다소 높지만 펀드 매매중개에 맞게 일회성의 판매수수료가 주된 비용이고, 펀드 매입 이후는 낮은 수준의 연간 펀드비용(주로 자산운용사의 운용보수)만 부담하기 때문에 초기의 높은 판매수수료를 희석시키려면 펀드의 장기보유가 유도될 수밖에 없다. Carhart(1997)의 연구에 의하면 1962년부터 1993년까지의 미국의 펀드 평균 판매수수료는 약 $7.33 \%$ 로 매우 높다. 그러나 높았던 판매수수료는 연금을 포함한 주식형 펀드 전체를 대상으로 한 수치이기는 하지만 미국에서도 약 1\%대 초반으로 낮아졌다(ICI, 2016, Fact Book, 56th Edition, p. 103). 이에 대해 우리나라는 초기의 가입비용에 거의 부담이 없는 대신 외국에 비하여 정기적으로 부담하는 연간 비용이 판매보수로 인하여 매우 높기 때문에 기존 펀드를 환매하고 신생펀드로 자금이 몰리기 쉬운 구조이다. 더욱이 자산운용사나 판매사들도 이런 경향에 따라, 자금을 유치하기 위하여 신설펀드 위주의 영업에 집중하고 있는 실정이다. 물론 국내 판매기관들이 
An Empirical Study on Size and Age Effects in Korean Equity Funds

높은 판매보수를 받기는 하지만 판매수수료가 일반화되지 않은 현실을 감안하면 꼭 외국 예에 비하여 우리나라 투자자들이 펀드비용을 더 많이 지불하는지는 충분히 논란이 있을 수 있다. 그러나 본 연구는 여기에 대해 논하려는 것이 아니고 문제는 이 와중에 외국에 비하여 압도적으로 많은 수의 펀드가 소외펀드화 될 위험성이 있다는 점과 여기에 우리나라 판매보수 체제가 중요한 원인이 되고 있다는 사실이다.

\section{2 선행연구의 검토}

\subsection{1 펀드의 규모효과 및 연령효과}

펀드의 규모는 운용 측면에서 규모의 경제 효과를 볼 수 있을 만큼 커야 하지만 그 규모가 너무 크면 운용성과에 부정적인 영향을 미친다는 것이 일반적인 견해이다. 규모의 경제(economy of scale), 시장충격(market impact) 등을 주제로 펀드의 규모효과에 대한 연구들은 다수 있지만, 펀드 연령이 성과에 미치는 영향에 대해서는 연구들이 많지 않으며 따라서 연령효과라는 용어도 거의 쓰이지 않는다. 다만 외국에서는 주로 헤지펀드와 관련하여 연령에 대한 연구가 이루어지고 있지만, 국내에서는 직접적인 펀드의 '연령효과' 연구는 없는 실정이다.

펀드의 규모효과와 관련하여 외국에서는 그 규모가 커지면 성과에 부정적 영향을 미치는지에 대한 연구들이 주류를 이루고 있다. 이는 선진국의 경우 펀드 규모가 국내보다 크기 때문에 규모가 커질 때 생기는 여러 현상, 예컨대 시장충격이나 유동성 문제 등으로 인해 펀드의 규모가 커질수록 오히려 규모의 비경제(diseconomy of scale)가 나타나서 펀드성과에 부정적인 영향을 줄 것으로 추정되기 때문이다. 그러나 국내 펀드는 그 규모가 선진국에 비해 매우 작고 다수의 펀드들이 존재하는 특징을 가지고 있다. 따라서 펀드의 최적 및 상하한 규모를 함께 분석해야 할 것이다. 일부 외국 연구들 중 Indro et al.(1999)은 펀드 규모의 상한뿐만 아니라 적정한 하한에 대하여도 분석하고 있으며 소규모펀드의 경우 일정 범위까지는 규모의 경제가 존재한다는 것을 보여주고 있다.

소외펀드에 대하여도 외국의 연구는 펀드 규모가 줄어들거나 오래되어서 생기는 소외펀드 현상보다는 자산운용사에 이득이 되는 펀드와 그렇지 않은 펀드간의 교차보조(cross-fund subsidization)에 초점을 맞추고 있다. 이 경우 이득이 되는 펀드는 운용보수 등 펀드비용이 높거나 혹은 대표펀드로 내세울 때 해당 자산운용사로 자금유입을 촉진할 수 있는 펀드를 말한다. 펀드성과와 자금흐름의 관계에 대하여 Gaspar et al.(2006) 등의 연구에서 대표펀드로의 자금유입 효과는 소외펀드에서의 자금유출보다 더 큰 소위 볼록한(convex relation) 형태의 자금흐름을 가지게 되므로 운용사로서는 교차보조를 할 유인이 있다고 한다. 한국에서는 주로 성과관리 편의(performance management bias)의 관점에서 소외펀드가 간접적으로 분석되고 있으나 직접적인 소외펀드에 관한 연구는 찾아보기 힘들다.

\subsection{2 국내외 선행연구 검토}

Yan(2008), Chen et al.(2004), Edelen et al.(2007), Indro et al.(1999) 등 외국의 선행연구 에서는 대체로 펀드의 규모효과가 음(-)인 결과들이 많으며 이는 주로 펀드 규모가 커질수록 시장충격 등 암묵적 거래비용이 증가한다는 유동성가설에 근거하고 있다. 더 나아가 Chan(2009)은

\section{6}


한국증권학회지 제48권 6호 (2019)

시장충격 비용(market impact costs) 이외에 이를 피하기 위한 매매위협 효과(transaction cost intimidation, 'intimidation' effect)도 동일하게 대형펀드의 성과를 저하시키고 있다고 주장한다.

펀드 연령이 성과에 미치는 영향과 관련하여서는 신생펀드가 유리하다는 헤지펀드에 대한 연구결과들이 많다. 예를 들어 Jones(2007)는 1996년 1월부터 2006년 7월까지 미국의 헤지펀드를 대상으로 1 백만 달러 이하, 5 백만 달러 이상과 그 중간 규모의 3 개 그룹으로 나누어 소규모펀드가 성과가 가장 양호함을 보이고 있으며, 펀드 연령도 2 년 이하, 4 년 이상 및 그 중간 기간의 3 개 그룹으로 나누어 2 년 이하의 상대적 신생그룹이 가장 성과가 좋음을 보여주고 있다. 펀드연령이 성과에 미치는 영향에 대한 직접적인 연구는 아니지만 헤지펀드가 아닌 일반펀드에서도 신생펀드의 성과가 양호하다는 견해가 있는 반면, 이와는 반대로 오래된 펀드가 평가기준에서 유리하다고 주장하는 연구로서 Morey(2000)는 모닝스타에서 실시하는 등급(Morningstar ratings)에서 10 년 이상 된 펀드들이 더 유리한 등급을 받을 수 있는 시스템적 연령편의('age bias')가 있음을 확인하고 있다.

펀드 비용과 관련하여 Morey(2003)는 판매수수료가 있는 펀드(load fund)와 없는 펀드(noload fund)의 성과를 비교하면서 기존 연구와 달리 판매수수료 조정 성과(load-adjusted performance) 개념을 도입하여 이를 비교하고 있다. 즉, 1993년부터 1997년까지 미국 모닝스타의 펀드를 대상으로 판매수수료 조정성과에서는 판매수수료를 받는 펀드가 그렇지 않은 펀드에 비하여 낮은 성과를 보였다. 또한 펀드연령에 따라 그 성과를 분석하였는데 이를 연령효과('age effect')라고 부르면서 낮은 연령의 펀드('young fund')의 성과가 우월하게 나타났음을 밝히고 있다.

국내에서 펀드의 규모효과에 대한 연구로서 Lee(2008), Lee(2011), Ban and Choe(2011)은 대체로 양(+)의 규모효과를 보여주고 있다. 펀드연령 효과에 대한 연구로서, Cho(2011), Park and $\operatorname{Park}(2011)$ 은 직접적으로 펀드연령이 성과에 미치는 영향을 분석한 것이라기보다는 성과관리 편의나 펀드의 현금흐름을 분석하는 과정에서 오래된 펀드가 불리할 수 있음을 시사하고 있다.

Park(2005)는 1996년부터 2003년까지 국내 주식형, 채권형 펀드를 대상으로 한 투자행태에 관한 연구에서 펀드연령과 펀드 규모가 펀드의 현금흐름에 대하여 음(-)의 회귀계수를 가진다고 밝혔다. 즉, 새로운 펀드상품의 출시를 통해 수요를 확대하려는 국내 운용사들의 관행과 함께 국내 투자자들이 단기 투자속성을 가지기 때문에 시간이 지날수록 펀드자금 유출이 늘어난다고 하면서 국내 펀드의 단기화 현상과 연령에 대한 분석을 펀드의 자금흐름을 통하여 보여 주고 있다.

\section{3. 연구자료 및 방법론}

\section{1 연구자료와 자료 선택상의 한계}

\subsection{1 연구자료 및 변수의 정의}

펀드 자료는 주로 국내 펀드평가 기관인 (주)KG 제로인(Zeroin)에서 수집하고 펀드유형 분류도 제로인의 분류기준을 따른다. 약관상 최고 주식투자 한도가 $70 \%$ 를 초과하는 펀드를 
주식형이라고 하는데 이 중에서 일반 주식형과 중소형 주식형만을 분석 대상으로 한다. 구체적으로는 제로인에서 펀드의 기본자료와 월별 수익률, 각종 보수, 순자산 총액, 설정액, 자금흐름, 현금 유동성 및 주식 평가액, 주식 포트폴리오 등을 구하고 (주)에프앤가이드에서 주가지수(KOSPI)와 상장 종목의 월별주가, 재무제표, 기타 위험조정성과 모형에 필요한 자료를 구한다.

2006년 1월부터 2015년 12월까지 10년의 연구기간 동안 일반 주식형 펀드 자료 중 사모를 제외한 공모형 만을 포함하였고 배당형이나 테마형 펀드, 인덱스 펀드를 제외하였다. 모자형 펀드의 경우 비용부담을 하는 자펀드를 대상으로 하였고 자금유출이 제한된 폐쇄형을 포함하지 않고 개방형 펀드만을 분석 대상으로 하였다. 한편, 국내 펀드산업에서 분기점이 된 글로벌 금융위기 직후인 2009년 말을 기준으로, 2005년 1월부터 2009년 12월까지를 전반기, 2010년 1월부터 2015년 12월까지를 후반기로 구분한다. 본 연구와 동일한 방법론과 유사한 주제(‘자투리 펀드')를 가지고 분석한 Ban and Choe(2013)의 연구와 비교가 될 수 있는데 그들의 연구기간은 2001.7 2009.12 기간으로 본 연구의 전반기와 일부 겹치게 되며 본 연구의 후반기는 동 연구 결과와 관계가 없는 그 이후의 변화로 해석할 수 있다.

2007년부터 활성화되기 시작한 클래스펀드는 투자자에게는 다양성을 제공하지만 펀드분석을 위한 자료처리 시 주의가 요구된다. 클래스펀드는 크게 A형과 C형으로 나누어지는데, A형은 일회성의 일정한 판매수수료를 부담하는 대신 매년 부담하게 되는 판매보수가 상대적으로 낮으며, $\mathrm{C}$ 형은 판매수수료가 없는 대신 판매보수가 $\mathrm{A}$ 형보다는 높다.

본 연구는 클래스펀드의 각 유형을 모두 동일한 하나의 펀드(제로인의 프라이머리 펀드)로 인식하고 총비용부담률을 이에 맞게 조정하였다. 총 비용부담률이라 함은 투자자가 부담하는 명시적 비용을 총괄한 금액을 순자산으로 나눈 개념으로 총보수보다 넓은, 실제 투자자가 부담하는 비용이다. 이는 투자자들이 펀드 가입 시 클래스펀드의 유형을 선택하는 유일한 기준은 '어느 정도 기간 동안의 투자가 두 유형의 비용체계에서 더 유리한가’라는 투자자가 부담하는 총비용부담률에 있기 때문이다. 제로인 자료의 펀드 총 보수에는 판매수수료는 포함되어 있지 않다. 판매수수료가 펀드로부터 지불되는 비용이 아니기 때문에 펀드평가사들이 이를 총 보수에 포함시키지 않는 것은 나름대로 일관성 있는 기준이라고 생각된다. 그러나 펀드에 관한 연구자료의 경우는 펀드로부터 직접 지불되는 비용이든 투자자가 직접 지불하는 비용이든 당연히 투자자의 펀드비용이고 또 실현 수익률도 이를 바탕으로 계산되어야 하므로 판매수수료를 펀드의 비용으로 인식하여야 하고 또 수익률도 이를 반영하여야 할 것이다.

본 연구에서는 펀드 순자산(펀드규모), 설정액, 설정일, 자금흐름 등의 자료는 프라이머리 펀드를 기준으로 한다. 그러나 프라이머리 펀드에는 비용이 표기되어 있지 않으므로, 각 프라이 머리 펀드에 매치되는 클래스펀드의 $\mathrm{A}, \mathrm{C}$ 유형에서 판매수수료가 있는 $\mathrm{A}$ 형의 판매수수료를 2.5 년으로 연할하여 $\mathrm{A}$ 형의 판매보수에 합산하여 $\mathrm{A}$ 형 판매보수를 현실화 시켜준 후 다시 이를 $\mathrm{C}$ 형의 판매보수와 금액 가중 합산하였다. 연할하는 2.5 년에 대해서는 사전적, 합리적으로 추정할 수밖에 없으므로 주식형 펀드 평균 예상 투자기간을 실무 관행 등을 고려하여 2.5년으로 추정하였다. Joo et al.(2009)에 나타난 투자자의 펀드보유 기간과 주식형 펀드가 채권형 펀드보다 상대적으로 장기 보유됨을 고려하였다. 또한 한국금융투자자 보호재단(KFIPF)에서 발간하는 
한국증권학회지 제48권 6호 (2019)

‘2016년 펀드 투자자 조사결과’와 한국금융투자협회(KOFIA)의 ‘금융투자자의 투자실태에 관한 조사보고서(2013)'에서도 주식형펀드 보유기간을 이와 유사하게 추정하고 있다.

펀드수익률과 관련하여서도 클래스펀드는 주의를 요한다. 앞서 본대로 펀드평가사의 자료에는 클래스펀드 $\mathrm{A}$ 형에서 지불되는 판매수수료를 총보수에 포함시키지 않기 때문에 $\mathrm{A}$ 형 펀드의 수익률은 $\mathrm{C}$ 형보다는 항상 높게 평가되어 처리되고 있다. 이것은 펀드수익률의 상향 왜곡을 초래하고 있어 이를 수정해야 한다. 기존연구에서 Morey(2003)는 판매수수료를 수취하는 'load fund'의 성과를 정확히 분석하기 위하여 판매수수료 조정성과('load-adjusted performance') 개념을 도입하여 선취수수료를 5 년에 걸쳐 연할하여 로드펀드의 비용을 현실화하고 있다. 이에 따라 본 연구에서도 앞서 설명한대로 보수 현실화를 위해 추가된 만큼의 A형의 판매보수를 $\mathrm{A}$ 형의 수익률에서 차감한 후 이를 순자산가치로 가중평균하여 해당 클래스펀드의 수익률을 계산하였다.

본 연구를 위한 주요 변수를 정의하면, 먼저 펀드 규모와 펀드 패밀리1) 규모는 자연로그를 취하여 총 순자산가치(total Net Asset Value)의 자연로그(LOGTNA), 패밀리 규모(family size)의 자연로그(LOGFAMSIZE)라고 표기한다. 펀드 규모는 해당펀드의 순자산가치이며, 펀드의 패밀리 규모는 해당 펀드가 속한 패밀리의 총 순자산가치에서 펀드 규모와의 상관관계를 완화시키기 위해 해당 펀드의 순자산가치를 차감하여 계산한다. 펀드연령(AGE)은 펀드의 설정일로부터의 기간이며 펀드의 총비용부담률(EXPRATIO: expense ratio)은 투자자가 부담하는 명시적인 비용을 순자산으로 나누어 계산된다. 여기에는 판매보수율(S. F. RATIO: sales fee ratio)과 운용보수율(Mgt. F. RATIO: management fee ratio), 수탁기관 보수 등 투자설명서나 약관에 명시된 모든 비용을 포함한다. 이 펀드비용은 시점에 따라 변화하지 않는다. 펀드평가사가 제공하는 펀드비용은 보수 인하조치가 있으면 이를 펀드설정일로부터 소급하여 변경처리하고 있기 때문이다.

펀드의 자금흐름(FLOW)은 제로인 자료를 그대로 사용하지 않고 시점 $\mathrm{t}$ 의 순자산에서 시점 $\mathrm{t}-1$ 의 순자산 $\times(1+$ 해당펀드의 기간 손익률 $)$ 을 차감하여 이 수치를 시점 $\mathrm{t}-1$ 의 순자산으로 나누어 산출하였다. 펀드의 현금보유비중(CASH RATIO)은 현금 및 현금 등가물을 모두 포함한 금액(현금, 예금, 콜, $\mathrm{CD}, \mathrm{CP}, \mathrm{RP}$ 등)을 해당펀드의 순자산으로 나누어 구한다. $\mathrm{FUNDRET}$ (Fund Return)은 펀드의 위험조정 수익률 즉, 각각의 성과 벤치마크로 조정된 수익률을 의미하며 본 연구에서는 시장조정수익률, CAPM 및 Carhart의 4요인 모형으로 조정된 수익률을 말한다.

\subsection{2 펀드자료 선택 기준}

연구기간 동안 존재한 모든 펀드를 대상으로 하여 생존편의(survivorship bias)의 문제를 제거하였다. 다만 모든 펀드를 대상으로 하는 것은 생존편의의 문제는 완화시킬 수 있으나, 설정한 지 얼마 안 되는 신생펀드나 소규모펀드를 모두 포함하게 되므로 인큐베이터 펀드 (incubator fund) 문제로 대표되는 성과 상향편의(upward bias)의 또 다른 문제를 야기할 수 있다.

1) 해당 펀드가 설정된 동일(자산운용) 회사에서 설정한 모든 펀드를 포괄하여 지칭하는 개념이며 광의로는 해당 자산운용사나 그 계열사를 통칭하는 경우도 있다. 
이와 관련하여 Evans(2010)는 1996년부터 2005년까지의 미국 국내 주식형의 신설펀드 중 약 $23 \%$ 가 인큐베이터2)되었고 위험조정 수익률 기준으로 연간 약 $3.5 \% \mathrm{p}$ 만큼 그렇지 않은 펀드의 수익률을 상회하였는데 인큐베이션 이후 기간에서는 이러한 우월한 수익률은 사라진다고 보고하고 있다. 이에 따라 이러한 인큐베이터 펀드들은 성과의 상향편의를 초래하는데 이를 완화시키기 위해서는 펀드연령이 3년 이상 된 것만을 취하는 방법과 2천5백만 달러 이상 규모의 펀드를 대상으로 하는 방법이 있으며 전자의 방법이 더 확실하다고 주장한다. Chen et al.(2004)도 상향편의에 대해서 언급하고 1 천 5 백만 달러 이하의 펀드 규모에서는 상향편의가 문제된다는 Elton et al.(2001)의 연구를 인용하고 있다.

이 부분에 대해서는 국내 기존연구에서 그다지 논의가 없었다. Ban and Choe(2013)에서는 인큐베이션 문제를 경감시키기 위해 설정 후 1 년 이상 된 펀드만을 대상으로 하고 있다. 또한 $\mathrm{Ko}(2014)$ 는 50억 원 이상의 펀드만을 대상으로 하였고 해지 이전 6 개월간의 자료도 배제하고 있다. 본 연구는 국내 주식형 펀드의 규모와 연령이 펀드성과에 미치는 영향에 대한 분석이고 특히 소외펀드에 대한 분석이 중요하기 때문에 생존편의가 없어야 하며 따라서 규모가 작은 펀드를 완전 배제하는 것은 바람직하지 않다. 또한 외국과 펀드연령이 크게 차이 나는 상황을 고려하면 신생펀드를 외국의 예와 같이 모두 배제할 수도 없다.

본 연구에서는 5 분위로 나눈 규모별 그룹 중 소규모펀드 그룹에 속하는 1,2 분위와 그 이상 자산규모인 3 5분위 그룹을 구분하여 전체 펀드 분석과 함께 소규모펀드와 중대형펀드를 비교하여 분석하는 것으로, 혹 발생할 수 있는 소규모펀드로 인한 분석왜곡, 특히 상향편의를 경계하고자 한다. 다만, 분석대상이 되는 펀드는 설정 후 6 개월이 경과한 펀드만을 대상으로 한다. 6 개월 이전 기간은 포트폴리오가 구성되면서 급속한 자금유입이 있는 시기이므로 성과가 왜곡될 수 있기 때문이다.

이에 따라 연구대상 펀드 수는 1,040 개이며 펀드월(fund months) 수는 53,298개이다. 기초 통계량은 <표 2-1>에서처럼 모든 표본을 펀드 규모에 따라 5분위로 나누었는데 일정한 금액 기준이 아닌 분위별로 거의 동일한 표본 수가 할당되도록 나누었다. 전월의 순자산 총액을 기준으로 다음 달의 펀드 분위 그룹을 결정하였으며 이렇게 결정된 각 변수들의 분위 그룹별 평균(횡단면 평균, cross-sectional averages)을 대상 기간 동안 시계열 평균(종단면 평균, time-series averages)하였다.

이 표에서 가장 특징적인 점은 전반적으로 펀드 규모(TNA)가 매우 작아 1,2 분위 그룹은 정책당국이 임의 해지를 유도하고 있는 50억 원 미만에 속한다는 사실이다. 그리고 이 두 그룹의 펀드 수는 전체 펀드수의 약 $40 \%$ 에 달한다. 본 연구와 유사한 분위 그룹 분류방식을 취한 Ban and Choe(2013)는 3분위 그룹까지인 전체 펀드수의 약 $60 \%$ 가 평균 순자산 50 억 원에 못 미쳤고, 가장 규모가 큰 그룹의 평균 순자산이 1,780 억 원으로 본 연구에서의 3,000 억 원에 훨씬 못 미치는 수준이었다. 이는 매우 작은 국내펀드의 규모가 후반기에 약간이나마 개선되었음을 알려 준다.

2) 자산운용사 등이 소규모 종자돈(seed money)으로 여러 펀드를 일정 기간 운용한 후 실적이 양호한 펀드를 일반에 공개(incubation survivors)하고 그렇지 못한 펀드를 소멸(incubation nonsurvivors) 시키는 행위를 의미한다. 


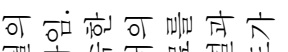

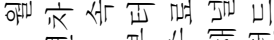

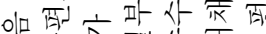

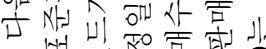

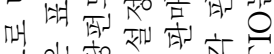

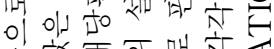

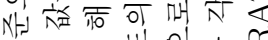

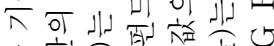

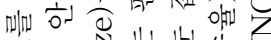

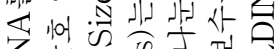

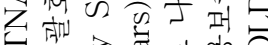

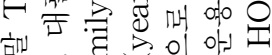

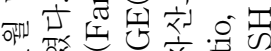

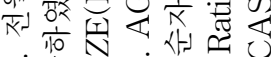

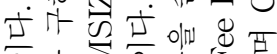

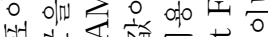

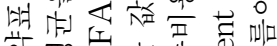

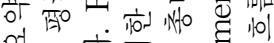

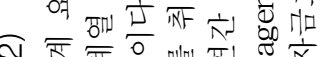
․ L

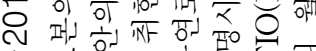

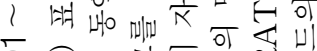

万。市

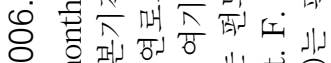

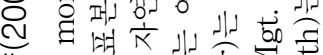

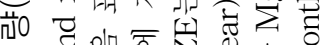
专 吅 때 0 에

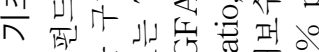

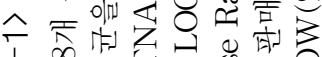
$\sim \log ^{\circ}$

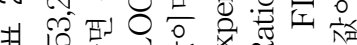

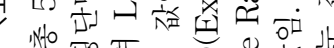

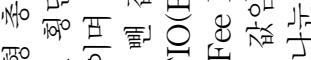
राँ

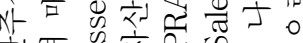

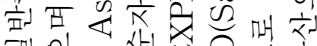
ol 0 난

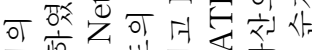
$\frac{0}{K}$ 夜 Z U

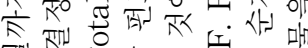

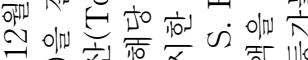
र्य एग

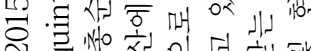
- 灰 $\frac{1}{10}$

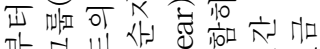

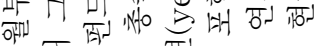
애 아

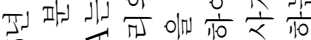

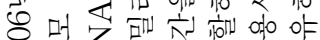

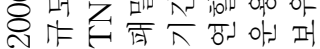

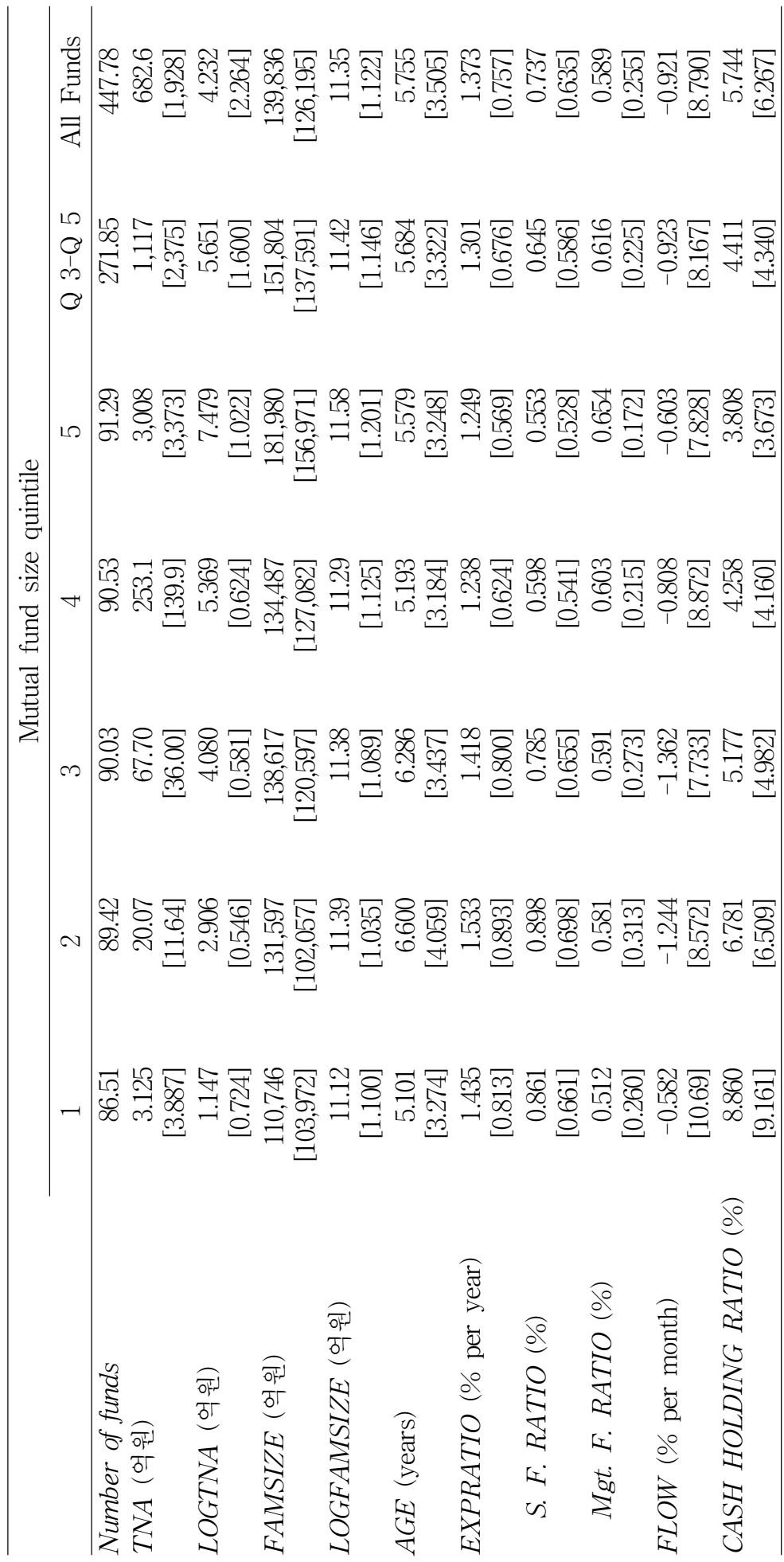


An Empirical Study on Size and Age Effects in Korean Equity Funds

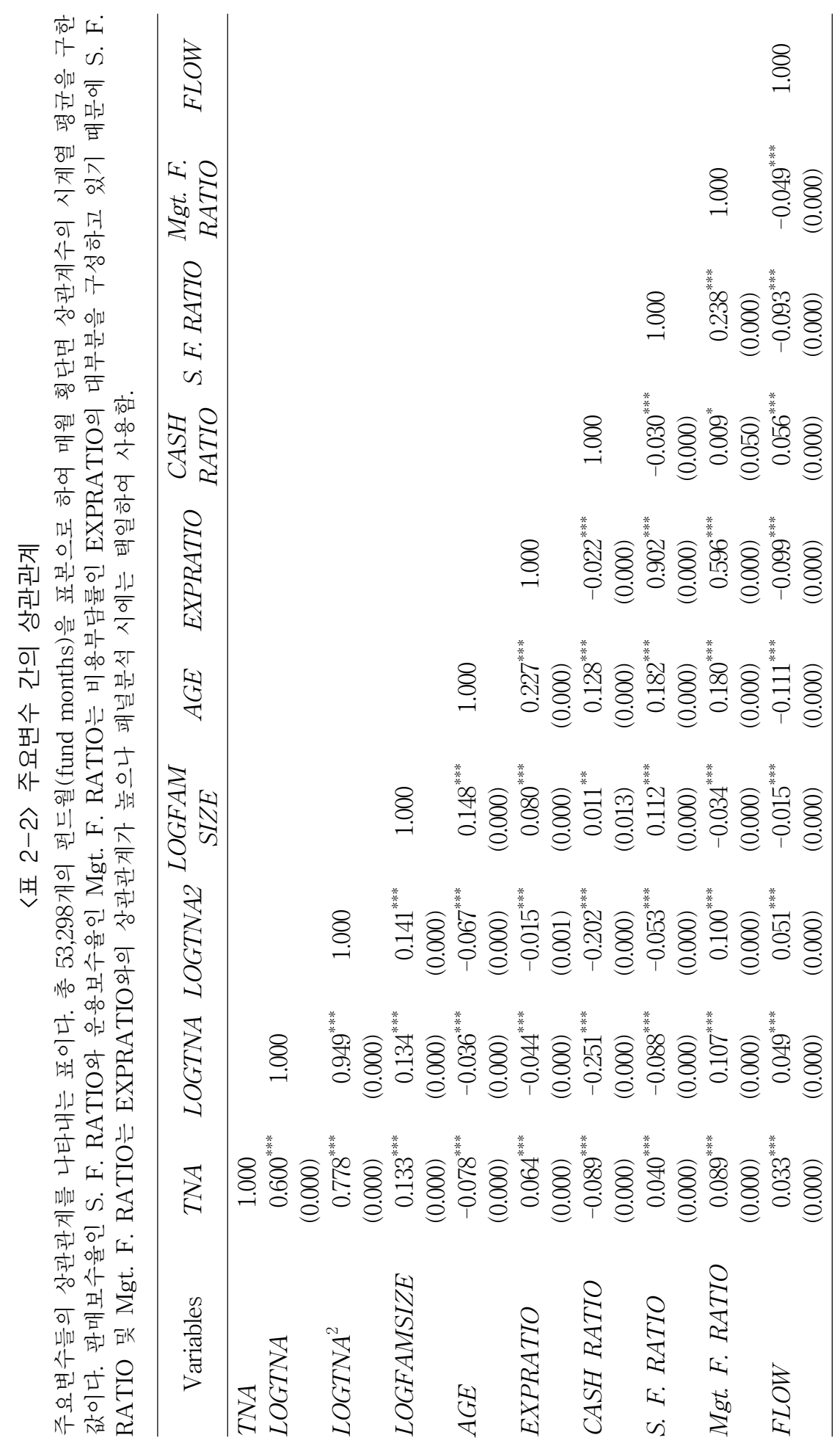


한국증권학회지 제48권 6호 (2019)

펀드연령에서도 모든 그룹의 평균이 5.55년으로 매우 짧으며 또한 분위 그룹별로도 거의 차이가 나지 않아 펀드가 장기화, 대형화되지 않고 있음을 볼 수 있다. 이와는 대조적으로 Chen et al.(2004)에서는 미국 펀드의 평균연령이 17.57년(1분위 그룹 제외 시)과 15.67년(전체 분위)으로 한국과 큰 차이가 나며, 더욱이 가장 규모가 작은 그룹인 1분위 그룹(8.17년)과 가장 규모가 큰 그룹인 5 분위 그룹(25.16년) 사이에 평균연령 차이가 3 배 이상으로 나타나서 미국펀드의 장기화, 대형화 현상을 뚜렷이 보여주고 있다.

또 다른 특징으로는 규모가 작은 펀드 그룹일수록 펀드의 총비용부담률이 높다는 점이다. 구체적으로 판매보수율은 소규모펀드 그룹이 더 높은 데 비해 운용보수율은 중대형펀드 그룹이 더 높다. 그러나 소규모펀드 그룹과 중대형펀드 그룹이 부담하는 판매보수율의 최대 차이는 약 $34.5 \mathrm{bp}$ 인데 비하여 운용보수율에서의 차이는 약 $14.2 \mathrm{bp}$ 로, 판매보수가 소규모펀드 그룹의 총비용부담률을 높이는 주요 요인이 되고 있다.

이러한 현상은 <표 2-2>의 주요변수들 간의 상관관계 표에서도 그대로 나타나고 있다. 펀드 규모(LOGTNA)는 펀드연령(AGE)과 음 $(-)$ 의 상관관계에 있는데, 이는 강한 양 $(+)$ 의 관계 $(+0.44)$ 를 보인 Chen et al.(2004)의 결과와는 정반대이다. 또한 펀드연령과 펀드의 총비용부담률 사이에 양(+)의 관계가 나타나는데, 이 또한 음(-)의 관계를 보인 Chen et al.(2004)의 결과와 반대이다.

결국 외국의 경우 펀드가 오래될수록 그 규모가 커지고 총비용부담률은 줄어드는데, 한국은 펀드가 오래될수록 오히려 규모가 작아지고 총비용부담률은 늘어나고 있다. 국내 펀드들의 소형화, 단기화 현상은 펀드의 총비용 부담률과 결합되어 소외펀드 현상이 쉽게 나타날 수 있음을 시사하고 있다.

\section{2 연구모형}

Chen et al.(2004)의 연구방법론과, 펀드의 최적규모 도출의 경우 Indro et al.(1999)의 방법론을 원용한다. 다만 Chen et al.(2004)과 차이점은 위험조정성과 모형에서 회귀분석 시 Fama and Macbeth(1973) 방법론 대신 일반적인 패널자료 회귀분석 방법 중 고정효과모형(fixed effect model, $\mathrm{FEM}$ )을 택하여 시간 고정효과를 통제하고 펀드 수준에서 클러스터링(clustering)을 하여 조정된 표준오차를 사용한다. 또한 위험조정 성과모형으로 시장조정 수익률, $\mathrm{CAPM}$ 및 Carhart(1997)의 4요인 모형을 사용하고자 한다. 시장조정 수익률 모형은 각 펀드의 수익률에서 시장수익률을 차감함으로써 구한다 $\left(R_{i, t}-R_{M, t}\right)$. CAPM 모형에서 무위험 수익률은 $\mathrm{CD} 91$ 일물의 수익률로 계산한다. Fama and French(1993)의 3요인 모형에 Jegadeesh and Titman(1993)이 지적한 모멘텀 이상현상(momentum anomaly)을 고려한 Carhart의 4요인 모형은 다음과 같다.

$$
R_{i, t}-R_{F, t}=\alpha_{i}+\beta_{i}\left(R_{M, t}-R_{F, t}\right)+s_{i} S M B_{t}+h_{i} H M L_{t}+u_{i} U M D_{t}+\epsilon_{i, t}
$$

SMB: Fama-French 3요인 모형에서 소형주-대형주 요인 수익률

$H M L$ : Fama-French 3요인 모형에서 가치주-성장주 요인 수익률

$U M D$ : Carhart의 4요인 모형에서 모멘텀 요인(momentum factor)으로, 본 연구에서는 과거 6 개월 승자 주식-패자 주식 요인 수익률 
An Empirical Study on Size and Age Effects in Korean Equity Funds

패널분석 등 모든 경우에 4-Factor Adj. Return(VW)는 가치가중 벤치마크 수익률을, 4-Factor Adj. Return(EW)은 동일가중 벤치마크 수익률을 나타낸다. 외국에서는 요인 포트폴리오 수익률 계산 시 주로 가치가중을 사용하지만 우리나라의 경우 코스피지수를 구성하는 상위 20개사의 시가총액 비중이 매우 높아 상대적으로 변동성이 낮은 이들 기업의 수익률이 지나치게 반영됨(Kim and Byun, 2011)을 피하고 또 실제 결과도 상당히 달랐으므로 둘 다 위험조정 성과지표로 사용한다.

다음으로 펀드 규모가 그 성과에 미치는 영향을 분석하기 위해 펀드 규모별 포트폴리오를 구축한다. 즉, 모든 펀드들을 월초에 그 직전 월의 규모(순자산 총액)를 기준으로 하여 5 개 분위로 그룹을 나눈다. 펀드를 규모에 따라서 매월 리밸런싱(rebalancing)하여, 나누어진 그룹별로 식 (2)의 회귀식을 시계열 기간 동안 실행하여 각각의 계수를 추정한 후 해당 펀드별로 그 소속된 그룹의 추정된 계수를 각 위험조정 성과모형에 대입하여 각각의 위험조정 수익률을 구한다.

$$
R_{k, t}-R_{F, t}=\alpha_{k}+\beta_{k}\left(R_{M, t}-R_{F, t}\right)+s_{k} S M B_{t}+h_{k} H M L_{t}+u_{k} U M D_{t}+\epsilon_{k, t}
$$

$k$ (분위그룹 $)=1, \ldots, 5$

$R_{k, t}$ : 시점 $\mathrm{t}$ 에서 $\mathrm{k}$ 분위 그룹의 수익률

<표 3>은 Chen et al.(2004)와 같은 방법으로 계산한 위험조정 성과지표의 위험요인과 그 계수들을 보여주고 있다. 패널 $\mathrm{A}$ 에서 시장위험 보상율인 $\left(R_{M}-R_{F}\right)$ 는 월 평균 $+0.10 \%$ 로 본 연구기간의 전반부를 다룬 기존 연구들과 비교하면 크게 낮아졌는데3) 이는 후반기 내내 주가지수가 횡보한 결과로 보인다. $\mathrm{SMB}$ 요인은 월 $+0.29 \%$ 로 오히려 높아졌는데 대형주 위주로 주가지수가 크게 상승하는 국면이 아니라 후반기 지수가 횡보하면서 중소형주에 대한 투자가 수익률에서 우월하였음을 추정케 한다. $\mathrm{HML}$ 요인은 월 $+1.16 \%$ 로 기존연구와 마찬가지로 국내 주식시장에서 가치주 투자는 양호한 수익률을 보이고 있음을 알 수 있다. 끝으로 UMD 모멘텀 요인은 월 $+1.79 \%$ 로 과거 6 개월간의 승자 포트폴리오가 패자 포트폴리오보다 수익률 측면에서 지속적으로 우위를 보임으로써 국내 시장에서 모멘텀 거래전략이 유효함을 보여주고 있다.

패널 $\mathrm{B}$ 와 패널 $\mathrm{C}$ 에서 성과지표로서의 알파를 살펴보면 $\mathrm{CAPM}$ 모형의 경우 1 분위와 3 분위 펀드그룹의 성과가 상대적으로 양호하며 대형펀드 그룹인 5 분위 그룹은 약간 떨어지고 있다. 4 요인 모형의 알파는 1 분위가 양호하지만 전체적으로는 의미있는 양 $(+)$ 의 초과수익률이라 하기 어렵다. 기존 국내의 연구결과로서 Kang and Lee(2010)에서는 2001년 1월부터 2007년 12 월까지의 국내 공모 주식형 펀드 분석 결과 두 모형에서 각 연 $2.6 \%$ 와 연 $3.12 \%$ 의 양 $(+)$ 의 초과수익률이 발견되었으며 Ban and Choe(2013)에서는 2001년 7월부터 2009년 12월까지의 국내 공모 주식형 펀드를 대상으로 규모에 따른 위험조정 성과분석을 하였는데 월 $0.06 \% \sim 0.22 \%$ 수준의 알파를 확인하고 있다.

3) Ban and Choe(2013)에서는 월 0.97\%로 매우 높다. 참고로 이 연구에서 SMB는 월 - $0.9 \%$, HML은 월 $1.59 \%$ 이다. 
$R_{M}-R_{F}$ 의 계수는 시장위험에 대한 각 펀드의 체계적 위험인 베타를 의미하는데 소규모 펀드일수록 베타가 낮아지고 있음을 알 수 있다. 5그룹과 1그룹의 베타차이는 CAPM과 4요인모형에서 각각 0.069 와 0.059 인 데, 가장 규모가 큰 펀드그룹에 비하여 가장 규모가 작은 펀드그룹은 이 수준만큼 유동성을 더 확보하고 있는 것으로 해석할 수 있다. 이 수준의 차이는 외국 예와 유사하게 보이며 Chen et al.(2004)은 3요인, 4요인 모형 모두 약 0.06 수준의 차이를 확인하면서 소규모 펀드그룹의 베타가 약간 낮지만 그다지 큰 차이가 아니라고 표현하고 있다. Ban and Choe(2013)에서는 베타로 추정되는 5그룹과 1그룹의 현금보유 비중의 차이는 약

\section{〈표 3〉 위험조정 성과모형의 통계 요약표}

Panel A: 위험요인 통계 요약표(Summary statistics of the factors)

각 위험조정 벤치마크의 위험요인 자체의 통계 요약표를 보여주고 있다. $R_{M}-R_{F}$ 는 가치 가중하여 산출된 시장(KOSPI)수익률에서 무위험(Risk-free) 이자율을 차감한 것이며 무위험이자율은 CD 91일물을 사용하였다. $\mathrm{SMB}$ 는 소형주 포트폴리오 수익률에서 대형주 포트폴리오 수익률을 뺀 값이며 $\mathrm{HML}$ 은 높은 장부가 주식 포트폴리오 수익률에서 낮은 장부가 주식 포트폴리오 수익률을 뺀 값이고 $\mathrm{UMD}$ 는 과거 6 개월 승자 포트폴리오 수익률에서 패자 포트폴리오 수익률을 뺀 값이다. Carhart 모형(1997)은 동일가중 방식에 의한 4 요인 모형이다.

\begin{tabular}{|c|c|c|c|c|c|c|}
\hline \multirow{2}{*}{ Factor } & \multirow{2}{*}{ Mean Return } & \multirow{2}{*}{$\mathrm{SD}$ of return } & \multicolumn{4}{|c|}{ Cross-'-correlations } \\
\hline & & & $\mathrm{R}_{\mathrm{M}}-\mathrm{R}_{\mathrm{F}}$ & SMB & HML & UMD \\
\hline$R_{M}-R_{F}$ & $0.10 \%$ & $5.13 \%$ & 1.00 & $\begin{array}{l}-0.051^{* * *} \\
(0.000)\end{array}$ & $\begin{array}{c}0.162^{* * *} \\
(0.000)\end{array}$ & $\begin{array}{l}0.244^{* * * *} \\
(0.000)\end{array}$ \\
\hline SMB & $0.29 \%$ & $4.23 \%$ & & 1.00 & $\begin{array}{l}-0.241^{* * *} \\
(0.000)\end{array}$ & $\begin{array}{l}-0.115^{* * *} \\
(0.000)\end{array}$ \\
\hline HML & $1.16 \%$ & $3.06 \%$ & & & 1.00 & $\begin{array}{l}0.194^{* * *} \\
(0.000)\end{array}$ \\
\hline UMD & $1.79 \%$ & $5.06 \%$ & & & & 1.00 \\
\hline
\end{tabular}

Panel B: CAPM 요인 계수치(Loadings calculated using the CAPM)

펀드 규모에 따라 5 분위로 분류된 각 그룹별로, CAPM 위험조정 벤치마크의 각 요인별 계수치(loadings)를 보여준다. Alpha는 위험조정 벤치마크를 초과하는 수익률을 의미한다.

\begin{tabular}{|c|c|c|}
\hline \multirow{2}{*}{ Portfolio } & \multicolumn{2}{|c|}{ 전체기간 } \\
\hline & Alpha & $\mathrm{R}_{\mathrm{M}}-\mathrm{R}_{\mathrm{F}}$ \\
\hline 1 (small) & $\begin{array}{c}0.212 \%^{* *} \\
(2.26)\end{array}$ & $\begin{array}{c}0.861^{* * *} \\
(48.75)\end{array}$ \\
\hline 2 & $\begin{array}{c}0.166 \%{ }^{*} \\
(1.72)\end{array}$ & $\begin{array}{c}0.878^{* * *} \\
(48.53)\end{array}$ \\
\hline 3 & $\begin{array}{c}0.219 \%{ }^{*} \\
(1.95)\end{array}$ & $\begin{array}{c}0.914^{* * *} \\
(43.14)\end{array}$ \\
\hline 4 & $\begin{array}{c}0.191 \%{ }^{*} \\
(1.78)\end{array}$ & $\begin{array}{c}0.909^{* * *} \\
(45.18)\end{array}$ \\
\hline 5 (large) & $\begin{array}{r}0.154 \% \\
(1.28)\end{array}$ & $\begin{array}{c}0.930^{* * *} \\
(41.15)\end{array}$ \\
\hline
\end{tabular}


An Empirical Study on Size and Age Effects in Korean Equity Funds

〈표 3〉 위험조정 성과모형의 통계 요약표(계속)

Panel C: 4요인 모형의 요인 계수치(Loadings calculated using the 4-Factor model)

펀드 규모에 따라 5 분위로 분류된 각 그룹별로, Carhart 4요인모형의 각 요인별 계수치(loadings)를 보여준다. 용어 정의는 Panel A에서와 동일하다.

\begin{tabular}{lrcccc}
\hline \multirow{2}{*}{ Portfolio } & \multicolumn{5}{c}{ 4-Factor Model } \\
\cline { 2 - 5 } & Alpha & $\mathrm{R}_{\mathrm{M}}-\mathrm{R}_{\mathrm{F}}$ & $\mathrm{SMB}$ & $\mathrm{HML}$ & UMD \\
\hline \multirow{2}{*}{1 (small) } & $0.082 \%$ & $0.842^{* * *}$ & -0.002 & -0.003 & $0.074^{* * *}$ \\
& $(0.81)$ & $(48.00)$ & $(-0.07)$ & $(-0.09)$ & $(4.00)$ \\
& $0.024 \%$ & $0.859^{* * *}$ & 0.001 & 0.025 & $0.062^{* * *}$ \\
3 & $(0.23)$ & $(47.00)$ & $(0.03)$ & $(0.80)$ & $(3.19)^{* *}$ \\
& $0.027 \%$ & $0.889^{* * *}$ & -0.007 & 0.045 & $0.076^{* * *}$ \\
4 & $(0.23)$ & $(42.13)$ & $(-0.25)$ & $(1.26)$ & $(3.43)$ \\
& $0.005 \%$ & $0.885^{* * *}$ & -0.005 & 0.042 & $0.075^{* * *}$ \\
5 (large) & $(0.04)$ & $(44.31)$ & $(-0.20)$ & $(1.24)$ & $(3.57)$ \\
& $-0.061 \%$ & $0.901^{* * *}$ & -0.025 & $0.070^{*}$ & $0.075^{* * *}$ \\
& $(-0.48)$ & $(40.54)$ & $(-0.94)$ & $(1.83)$ & $(3.20)$ \\
\hline
\end{tabular}

0.118 로 매우 크다고 분석하였으며 각 시점의 횡단면 평균을 다시 시계열 평균하여 직접 관찰한 현금보유 비중은 본 논문과 같은 방식의 동일가중 방식의 경우는 5 그룹과 1 그룹의 차이가 무려 $19.63 \%$ 에 달한다(Ban and Choe, 2013: 354, 356). 따라서 이 논문은 이러한 특징에 대한 추가분석을 통하여 현금보유 비중이 위험조정 성과에 영향을 주는 가장 유력한 변수라고 결론을 내리고 있다.

한편, 통제변수들을 고려한 규모효과 모형과 펀드의 최적규모를 구하기 위한 모형은 다음과 같이 표시된다.

$$
\begin{aligned}
\text { FUNDRET }_{i, t}= & \mu+\beta_{1} \operatorname{LOGTNA}_{i, t-1}+\beta_{2} \operatorname{LARGE}_{i, t-1}+\beta_{3} \text { LOGTNA }_{i, t-1} \times \operatorname{LARGE}_{i, t-1} \\
& +\sum_{i=1}^{N} \gamma_{i} X_{i, t-1}+\epsilon_{i, t}
\end{aligned}
$$

여기서 LARGE는 펀드 규모의 더미변수로서 중대형펀드의 경우 1 의 값을 소규모펀드는 0 의 값을 취한다. 그리고 통제변수들 $\left(X_{i, t-1}\right)$ 은 앞서 정의한 변수들로서 $L O G F A M S I Z E_{i, t-1}, A G E_{i, t-1}$, $\operatorname{EXPRATIO}_{i, t-1}, F L O W_{i, t-1}, \mathrm{CASH} R A T I O_{i, t-1}$, PAST $R E T U R N_{i, t}$ 을 포함한다. Indro et al.(1999)에서는 펀드의 규모효과를 분석하는 식에 펀드규모의 2차항을 포함시켜 비선형(nonlinear)관계를 보임으로써 펀드의 최적규모를 추정하고 있다. 본 연구에서도 식 (3)에서 더미 변수항을 빼고 대신 펀드규모 변수의 이차항을 포함시킨 식 (4)를 통해 펀드 규모효과의 선형성 여부를 확인하고 최적규모를 구하고자 한다.

$$
\operatorname{FUNDRET}_{i, t}=\mu+\beta_{1} \operatorname{LOGTNA}_{i, t-1}+\beta_{2}\left(\operatorname{LOGTNA}_{i, t-1}\right)^{2}+\sum_{i=1}^{N} \gamma_{i} X_{i, t-1}+\epsilon_{i, t}
$$


한국증권학회지 제48권 6호 (2019)

유동성가설 검증을 위해 Chen et al.(2004)은 소형주에 투자하는 펀드는 그렇지 않은 펀드에 비하여 투자 종목의 유동성에 더 민감하기 때문에 펀드 규모가 커지면서 펀드성과에 부정적인 영향을 받게 되는데 이를 더미변수를 추가하여 검증하고 있다. 또한 Indro et al.(1999)는 성장주 펀드의 경우 주로 소형주나 유동성이 부족한 주식일 경우가 많아 포트폴리오 유연성(portfolio flexibility)이 가장 떨어지므로 펀드 규모가 커지면 다른 펀드스타일에 비해 상대적으로 성과가 불리함을 확인하였다. 제로인의 자료상 소형주(스몰캡) 투자펀드 표본은 357 개로 너무 적어서 본 연구에서는 성장주펀드를 이용하여 유동성가설을 검증하고자 한다. 이에 따라 성장주펀드 (growth fund)에 대한 더미변수(GR_dummy)를 포함하고 성장주 투자 펀드의 경우 '1' 값, 그렇지 않은 펀드는 0 의 값을 취한다.

한편, 더미변수(GR_dummy)와 펀드규모 변수(LOGTNA) 간의 상호작용항(interaction term, 'LOGTNA $\times$ GR_dummy')의 계수인 $\phi_{3}$ 가 중요한데, 이는 성장주 투자 펀드로 인해 추가로 야기되는 차별적 규모효과를 나타낸다. 이 계수가 유의하게 음(-)으로 나타나면, 성장주 투자 펀드는 그 규모가 커짐으로 인하여 성과가 더 낮아지며, 유동성가설이 지지된다고 할 수 있다. 유동성가설 검증을 위한 식은 다음과 같다.

$$
\begin{aligned}
\text { FUNDRET }_{i, t}= & \mu+\phi_{1} \text { LOGTNA }_{i, t-1}+\phi_{2} G R_{\text {dummy }} \\
& +\phi_{3} \text { LOGTNA }_{i, t-1} \times G R_{\text {dummy }}+\gamma X_{i, t-1}+\epsilon_{i, t}
\end{aligned}
$$

그리고 펀드 연령효과 분석을 위해서 펀드 규모와 연령의 상호작용항을 변수로 사용하여 다음 모형으로 분석한다. 이 상호작용항의 계수 $\beta_{3}$ 는 펀드연령 변수로 인해 추가로 야기되는 차별적인 규모효과를 의미한다.

$$
\begin{aligned}
\text { FUNDRET }_{i, t}= & \mu+\beta_{1} \operatorname{LOGTNA}_{i, t-1}+\beta_{2} A G E_{i, t-1}+\beta_{3} \operatorname{LOGTNA}_{i, t-1} \times A G E_{i, t-1} \\
& +\sum_{i=1}^{N} \gamma_{i} X_{i, t-1}+\epsilon_{i, t}
\end{aligned}
$$

\section{4. 실증분석 결과}

\section{1 패널분석 결과}

펀드의 위험조정 성과를 종속변수로 하는 패널회귀분석을 한 결과, <표 4-1>에서 보는 바와 규모효과(LOGTNA)는 기존연구에서 보고되었던 양(+)의 효과가 사라지고 4 요인 동일가중 에서는 약하게 음(-)이고 전체적으로 유의하지 않다. 오히려 중대형펀드에서는 상호작용항 (LOGTNA $\times$ LARGE)의 계수가 모든 모형에서 음(-)으로 나타나 규모효과는 확실히 음으로 반전되고 있다. 즉 중대형펀드에서는 그 규모가 일정수준 이상 커질수록 성과가 낮아지는 현상이 나타나고 있다. 이는 글로벌금융위기 직후인 2009년 말을 기준으로 나눈 위기 이전기간(전반기: <표 4-2>)에 대체로 유의하지 않았던 중대형펀드의 상호작용항 계수가 위기 이후(후반기: 
An Empirical Study on Size and Age Effects in Korean Equity Funds

〈표 4-1〉 전체기간 소규모/중대형펀드 패널분석(2006.1 2015.12)

전체기간 전체펀드 그룹의 총 44,912개의 펀드월(fund months) 표본에 대하여 각 위험조정 벤치마크 대비 초과수익률('FUNDRET')을 종속변수로 하여 패널분석한 결과임. 패널분석 시 각 시점의 시간고정 효과를 통제하였고 'lag' 표시는 종속변수보다 한 기간 이전(t-1) 시점의 독립변수들을 의미함. LARGE는 중대형펀드를 나타내는 더미변수, TNA는 펀드의 순자산이며 FAMSIZE는 해당 펀드가 속한 패밀리의 총순자산에서 해당 펀드의 순자산을 차감한 값임. $\mathrm{AGE}$ 는 펀드의 연령, EXPRATIO는 펀드의 명시적 총비용을 순자산으로 나눈 값이며 판매수수료를 연할하여 포함하고 있다. S. F. RATIO(Sales Fee Ratio)는 판매보수를 순자산으로 나눈 값이며 판매수수료를 연할하여 포함하고 있으며 Mgt. F. RATIO(Management Fee Ratio)는 운용보수를 순자산으로 나눈 값임. FLOW는 해당 펀드의 최근 한 달간의 자금흐름이며 $\mathrm{CASH}$ RATIO는 현금 및 현금등가물을 순자산으로 나눈 값임. PAST RETURN은 최근 12 개월간의 누적수익률을 의미함. Market Adj. Return은 시장조정 수익률이며 CAPM Adj. Return은 CAPM을 사용한 조정수익률을, 4-Factor Adj. Return(VW)과 4-Factor Adj. Return(EW)은 각각 Carhart(1997) 방법론을 사용한 4요인 모형의 가치가중, 동일가중 조정수익률을 의미한다. 'LOG'는 자연로그를 취한 값이며 괄호 안의 수치는 유의수준을 나타내는 통계량 ' $\mathrm{t}$ '값이다.

\begin{tabular}{|c|c|c|c|c|}
\hline Variables & $\begin{array}{c}\text { (1) } \\
\text { Market Adj. } \\
\text { Return }\end{array}$ & $\begin{array}{c}(2) \\
C A P M \text { Adj. } \\
\text { Return }\end{array}$ & $\begin{array}{c}\text { (3) } \\
\text { 4-Factor Adj. } \\
\text { Return }(V W)\end{array}$ & $\begin{array}{c}\text { (4) } \\
\text { 4-Factor Adj. } \\
\text { Return (EW) }\end{array}$ \\
\hline lag LOGTNA & $\begin{array}{l}0.006 \\
(1.60)\end{array}$ & $\begin{array}{l}0.005 \\
(1.28)\end{array}$ & $\begin{array}{l}-0.006 \\
(-1.55)\end{array}$ & $\begin{array}{l}-0.007^{*} \\
(-1.85)\end{array}$ \\
\hline lag LARGE Dummy & $\begin{array}{l}0.187^{* * *} \\
(3.97)\end{array}$ & $\begin{array}{l}0.195^{* * *} \\
(3.84)\end{array}$ & $\begin{array}{l}0.172^{* * *} \\
(3.38)\end{array}$ & $\begin{array}{l}0.127^{* * *} \\
(2.51)\end{array}$ \\
\hline $\begin{array}{ll}\operatorname{lag} & L O G T N A \times \\
& \text { LARGE Dummy }\end{array}$ & $\begin{array}{l}-0.045^{* * *} \\
(-3.51)\end{array}$ & $\begin{array}{l}-0.047^{* * *} \\
(-3.32)\end{array}$ & $\begin{array}{l}-0.050^{* * *} \\
(-3.51)\end{array}$ & $\begin{array}{l}-0.038^{* * *} \\
(-3.51)\end{array}$ \\
\hline lag LOGFAMSIZE & $\begin{array}{l}-0.009 \\
(-1.13)\end{array}$ & $\begin{array}{l}-0.015 \\
(-1.63)\end{array}$ & $\begin{array}{l}-0.013 \\
(-1.46)\end{array}$ & $\begin{array}{l}-0.013 \\
(-1.45)\end{array}$ \\
\hline $\operatorname{lag} A G E$ & $\begin{array}{l}-0.007^{* * *} \\
(-2.94)\end{array}$ & $\begin{array}{l}-0.006^{* *} \\
(-2.47)\end{array}$ & $\begin{array}{l}-0.005^{* *} \\
(-2.15)\end{array}$ & $\begin{array}{l}-0.006^{* *} \\
(-2.33)\end{array}$ \\
\hline lag EXPRATIO & $\begin{array}{l}-0.089^{* * *} \\
(-5.39)\end{array}$ & $\begin{array}{l}-0.085^{* * *} \\
(-4.83)\end{array}$ & $\begin{array}{l}-0.082^{* * *} \\
(-4.65)\end{array}$ & $\begin{array}{l}-0.081^{* * *} \\
(-4.61)\end{array}$ \\
\hline lag S. F. RATIO & $\begin{array}{l}-0.088^{* * *} \\
(-4.11)\end{array}$ & $\begin{array}{l}-0.094^{* * *} \\
(-4.05)\end{array}$ & $\begin{array}{l}-0.090^{* * *} \\
(-3.89)\end{array}$ & $\begin{array}{l}-0.087^{* * *} \\
(-3.81)\end{array}$ \\
\hline lag Mgt. F. RATIO & $\begin{array}{l}-0.080^{* *} \\
(-2.23)\end{array}$ & $\begin{array}{r}-0.044 \\
(-1.13)\end{array}$ & $\begin{array}{l}-0.045 \\
(-1.15)\end{array}$ & $\begin{array}{l}-0.049 \\
(-1.26)\end{array}$ \\
\hline lag FLOW & $\begin{array}{l}0.001 \\
(1.29)\end{array}$ & $\begin{array}{r}0.002 \\
(1.27)\end{array}$ & $\begin{array}{l}0.001 \\
(1.18)\end{array}$ & $\begin{array}{r}0.001 \\
(1.19)\end{array}$ \\
\hline lag CASH RATIO & $\begin{array}{l}0.003 \\
(1.54)\end{array}$ & $\begin{array}{l}0.000 \\
(0.17)\end{array}$ & $\begin{array}{l}0.000 \\
(0.02)\end{array}$ & $\begin{array}{l}-0.000 \\
(-0.02)\end{array}$ \\
\hline PAST RETURN & $\begin{array}{c}0.014^{* * *} \\
(10.40)\end{array}$ & $\begin{array}{l}0.014^{* * *} \\
(9.30)\end{array}$ & $\begin{array}{l}0.014^{* * *} \\
(9.14)\end{array}$ & $\begin{array}{l}0.014^{* * *} \\
(9.29)\end{array}$ \\
\hline Monthly Fixed Effects & Yes & Yes & Yes & Yes \\
\hline Observations & 44,912 & 44,912 & 44,912 & 44,912 \\
\hline $\mathrm{R}$-squared & 0.132 & 0.320 & 0.290 & 0.290 \\
\hline
\end{tabular}


한국증권학회지 제48권 6호 (2019)

<표 4-3>)에는 뚜렷이 음으로 전환되고 있기 때문이다.4) 결국 후반기에서 유의하게 나타난 중대형펀드 그룹에서의 음(-)의 규모효과는, 전체펀드 그룹의 전반기의 양 $(+)$ 의 규모효과를 전체기간에서 상쇄하고 있다. 다만, 소규모펀드의 경우 전체기간에서 유의하게 양(+)으로 나타나 규모의 경제가 작용하고 있음을 알 수 있다.5)

〈표 4-2〉 전반기 소규모/중대형펀드 패널분석(2006.1 2009.12)

연구기간 전반기 전체펀드 그룹의 총 12,347 개의 펀드월(fund months)표본에 대하여 각 위험조정 벤치마크 대비 초과수익률('FUNDRET')을 종속변수로 하여 패널분석한 결과임. 패널분석 시 각 시점의 시간고정 효과를 통제하였고 'lag' 표시는 종속변수보다 한 기간 이전(t-1) 시점의 독립변수들을 의미함. LARGE는 중대형펀드를 나타내는 더미변수, TNA는 펀드의 순자산이며 FAMSIZE는 해당 펀드가 속한 패밀리의 총순자산에서 해당 펀드의 순자산을 차감한 값임. AGE는 펀드의 연령, EXPRATIO는 펀드의 명시적 총비용을 순자산으로 나눈 값이며 판매수수료를 연할하여 포함하고 있다. FLOW는 해당 펀드의 최근 한 달간의 자금흐름이며 CASH RATIO는 현금 및 현금등가물을 순자산으로 나눈 값임. PAST RETURN은 최근 12 개월간의 누적수익률을 의미함. Market Adj. Return은 시장조정 수익률이며 CAPM Adj. Return 은 CAPM을 사용한 조정수익률을, 4-Factor Adj. Return(VW)과 4-Factor Adj. Return(EW)은 각각 Carhart(97) 방법론을 사용한 4요인 모형의 가치가중, 동일가중 조정수익률을 의미한다. 'LOG'는 자연 로그를 취한 값이며 괄호 안의 수치는 유의수준을 나타내는 통계량 ' $\mathrm{t}$ '값이다.

\begin{tabular}{|c|c|c|c|c|}
\hline Variables & $\begin{array}{c}\text { (1) } \\
\text { Market Adj. } \\
\text { Return }\end{array}$ & $\begin{array}{c}(2) \\
C A P M A d j . \\
\text { Return }\end{array}$ & $\begin{array}{c}\text { (3) } \\
\text { 4-Factor Adj. } \\
\text { Return }(V W)\end{array}$ & $\begin{array}{c}\text { (4) } \\
\text { 4-Factor Adj. } \\
\text { Return }(E W)\end{array}$ \\
\hline lag LOGTNA & $\begin{array}{l}0.040^{*} \\
(1.81)\end{array}$ & $\begin{array}{l}0.032 \\
(1.29)\end{array}$ & $\begin{array}{l}0.020 \\
(0.82)\end{array}$ & $\begin{array}{l}0.003 \\
(0.11)\end{array}$ \\
\hline lag LARGE Dummy & $\begin{array}{l}0.241^{* * *} \\
(2.99)\end{array}$ & $\begin{array}{l}0.217^{* *} \\
(2.42)\end{array}$ & $\begin{array}{l}0.171^{*} \\
(1.92)\end{array}$ & $\begin{array}{r}0.071 \\
(0.81)\end{array}$ \\
\hline $\begin{array}{l}\text { lag LOGTNA× } \\
\text { LARGE Dummy }\end{array}$ & $\begin{array}{l}-0.041^{*} \\
(-1.77)\end{array}$ & $\begin{array}{l}-0.032 \\
(-1.21)\end{array}$ & $\begin{array}{l}-0.032 \\
(-1.19)\end{array}$ & $\begin{array}{l}-0.006 \\
(-0.23)\end{array}$ \\
\hline lag LOGFAMSIZE & $\begin{array}{r}0.021 \\
(1.41)\end{array}$ & $\begin{array}{l}0.003 \\
(0.18)\end{array}$ & $\begin{array}{l}0.005 \\
(0.38)\end{array}$ & $\begin{array}{r}0.006 \\
(0.42)\end{array}$ \\
\hline $\operatorname{lag} A G E$ & $\begin{array}{l}-0.023^{* * *} \\
(-3.67)\end{array}$ & $\begin{array}{l}-0.015^{\text {*** }} \\
(-2.35)\end{array}$ & $\begin{array}{l}-0.014^{* *} \\
(-2.29)\end{array}$ & $\begin{array}{l}-0.014^{* *} \\
(-2.37)\end{array}$ \\
\hline lag EXPRATIO & $\begin{array}{l}-0.133^{* * *} \\
(-5.02)\end{array}$ & $\begin{array}{l}-0.123^{* * *} \\
(-4.26)\end{array}$ & $\begin{array}{l}-0.120^{* * * *} \\
(-4.21)\end{array}$ & $\begin{array}{l}-0.120^{* * *} \\
(-4.25)\end{array}$ \\
\hline lag FLOW & $\begin{array}{l}-0.001 \\
(-0.24)\end{array}$ & $\begin{array}{l}-0.001 \\
(-0.35)\end{array}$ & $\begin{array}{l}-0.001 \\
(-0.57)\end{array}$ & $\begin{array}{l}-0.001 \\
(-0.53)\end{array}$ \\
\hline lag CASH RATIO & $\begin{array}{l}0.010^{* *} \\
(2.54)\end{array}$ & $\begin{array}{l}0.001 \\
(0.27)\end{array}$ & $\begin{array}{l}-0.001 \\
(-0.15)\end{array}$ & $\begin{array}{l}-0.002 \\
(-0.47)\end{array}$ \\
\hline PAST RETURN & $\begin{array}{l}-0.001 \\
(-0.33)\end{array}$ & $\begin{array}{l}-0.001 \\
(-0.24)\end{array}$ & $\begin{array}{l}-0.001 \\
(-0.38)\end{array}$ & $\begin{array}{r}-0.000 \\
(-0.20)\end{array}$ \\
\hline Monthly Fixed Effects & Yes & Yes & Yes & Yes \\
\hline Observations & 12,347 & 12,347 & 12,347 & 12,347 \\
\hline $\mathrm{R}$-squared & 0.248 & 0.421 & 0.393 & 0.393 \\
\hline
\end{tabular}

4) 더미변수를 빼고, 중대형펀드 표본만에 대한 분석에서도 음(-)의 규모효과가 매우 유의하게 나타났다.

5) 규모효과, 펀드연령 및 비용부담률 등의 회귀분석 결과에서 지면 관계상 기간별 이외에 펀드규모별 분석 결과표는 생략한다. 이하 생략하는 연구결과 표는 필요시 제공할 수 있다. 
An Empirical Study on Size and Age Effects in Korean Equity Funds

〈표 4-3〉 후반기 소규모/중대형펀드 패널분석(2010.1 2015.12)

후반기간 전체펀드 그룹의 총 32,565 개의 펀드월(fund months) 표본에 대하여 각 위험조정 벤치마크 대비 초과수익률('FUNDRET')을 종속변수로 하여 패널분석한 결과임. 패널분석 시 각 시점의 시간고정 효과를 통제하였고 'lag' 표시는 종속변수보다 한 기간 이전(t-1) 시점의 독립변수들을 의미함. LARGE는 중대형펀드를 나타내는 더미변수, TNA는 펀드의 순자산이며 FAMSIZE는 해당 펀드가 속한 패밀리의 총순자산에서 해당 펀드의 순자산을 차감한 값임. $\mathrm{AGE}$ 는 펀드의 연령, EXPRATIO는 펀드의 명시적 총비용을 순자산으로 나눈 값이며 판매수수료를 연할하여 포함하고 있다. FLOW는 해당 펀드의 최근 한 달간의 자금흐름이며 CASH RATIO는 현금 및 현금등가물을 순자산으로 나눈 값임. PAST RETURN은 최근 12 개월간의 누적수익률을 의미함. MKT_Adj_Return은 시장조정 수익률이며 CAPM_Adj_Return은 CAPM을 사용한 조정수익률을, 4-Factor Adj. Return(VW)과 4-Factor Adj. Return(EW)은 각각 Carhart(97) 방법론을 사용한 4요인 모형의 가치가중, 동일가중 조정수익률을 의미한다. 'LOG'는 자연로그를 취한 값이며 괄호 안의 수치는 유의수준을 나타내는 통계량 't값'이다.

\begin{tabular}{|c|c|c|c|c|}
\hline Variables & $\begin{array}{c}\text { (1) } \\
\text { Market Adj. } \\
\text { Return }\end{array}$ & $\begin{array}{c}(2) \\
C A P M A d j . \\
\text { Return }\end{array}$ & $\begin{array}{c}\text { (3) } \\
\text { 4-Factor Adj. } \\
\text { Return }(V W)\end{array}$ & $\begin{array}{c}\text { (4) } \\
\text { 4-Factor Adj. } \\
\text { Return }(E W)\end{array}$ \\
\hline$\overline{l a g}$ LOGTNA & $\begin{array}{l}0.020 \\
(1.61)\end{array}$ & $\begin{array}{l}0.022 \\
(1.53)\end{array}$ & $\begin{array}{l}0.024^{*} \\
(1.66)\end{array}$ & $\begin{array}{l}0.017 \\
(1.16)\end{array}$ \\
\hline lag LARGE Dummy & $\begin{array}{l}0.169^{* * *} \\
(2.98)\end{array}$ & $\begin{array}{l}0.178^{* * *} \\
(2.92)\end{array}$ & $\begin{array}{l}0.162^{* * *} \\
(2.64)\end{array}$ & $\begin{array}{l}0.144^{* *} \\
(2.36)\end{array}$ \\
\hline $\begin{array}{l}\text { lag LOGTNA× } \\
\text { LARGE Dummy }\end{array}$ & $\begin{array}{l}-0.041^{* * *} \\
(-2.83)\end{array}$ & $\begin{array}{l}-0.044^{* * *} \\
(-2.71)\end{array}$ & $\begin{array}{l}-0.049^{* * *} \\
(-3.00)\end{array}$ & $\begin{array}{l}-0.042^{* * *} \\
(-2.60)\end{array}$ \\
\hline lag LOGFAMSIZE & $\begin{array}{l}-0.014 \\
(-1.54)\end{array}$ & $\begin{array}{l}-0.015 \\
(-1.52)\end{array}$ & $\begin{array}{l}-0.015 \\
(-1.49)\end{array}$ & $\begin{array}{l}-0.015 \\
(-1.49)\end{array}$ \\
\hline $\operatorname{lag} A G E$ & $\begin{array}{r}-0.004 \\
(-1.37)\end{array}$ & $\begin{array}{r}-0.004 \\
(-1.53)\end{array}$ & $\begin{array}{r}-0.004 \\
(-1.40)\end{array}$ & $\begin{array}{r}-0.004 \\
(-1.34)\end{array}$ \\
\hline lag EXPRATIO & $\begin{array}{l}-0.050^{* *} \\
(-2.57)\end{array}$ & $\begin{array}{l}-0.050^{* *} \\
(-2.41)\end{array}$ & $\begin{array}{l}-0.049^{* *} \\
(-2.36)\end{array}$ & $\begin{array}{l}-0.049^{* *} \\
(-2.32)\end{array}$ \\
\hline lag FLOW & $\begin{array}{r}0.002 \\
(1.49)\end{array}$ & $\begin{array}{r}0.002 \\
(1.50)\end{array}$ & $\begin{array}{r}0.002 \\
(1.42)\end{array}$ & $\begin{array}{l}0.002 \\
(1.41)\end{array}$ \\
\hline lag CASH RATIO & $\begin{array}{l}0.002 \\
(1.36)\end{array}$ & $\begin{array}{r}0.003 \\
(1.49)\end{array}$ & $\begin{array}{l}0.003 \\
(1.63)\end{array}$ & $\begin{array}{l}0.003 \\
(1.64)\end{array}$ \\
\hline PAST RETURN & $\begin{array}{l}0.019^{* * *} \\
(12.38)\end{array}$ & $\begin{array}{l}0.020^{* * *} \\
(10.76)\end{array}$ & $\begin{array}{l}0.020^{* * *} \\
(10.78)\end{array}$ & $\begin{array}{l}0.020^{* * *} \\
(10.88)\end{array}$ \\
\hline Monthly Fixed Effects & Yes & Yes & Yes & Yes \\
\hline Observations & 32,565 & 32,565 & 32,565 & 32,565 \\
\hline $\mathrm{R}$-squared & 0.063 & 0.254 & 0.224 & 0.225 \\
\hline
\end{tabular}

전체 연구기간, 모든 성과 모형에서 공통적으로 매우 유의한 설명변수는 펀드연령(AGE), 펀드 비용부담률(EXPRATIO), 펀드의 과거 1년간 수익률(PAST RETURN)이었다. PAST RETURN이 양(+)의 값을 가지는 것은 <표 3> Panel A에서 모멘텀요인(UMD)이 높은 양의 값을 가진 것과 그 궤를 같이하며 이 현상은 특히 후반기(<표 4-3>)에서 두드러지고 있다.

펀드 연령이 성과에 미치는 영향과 펀드의 비용부담률은 펀드 성과와 음(-)의 관계를 가지지만 후반기는 전반기보다 이 현상이 완화되고 있어 2009년 말을 전후하여 실시된 보수인하조치나 
한국증권학회지 제48권 6호 (2019)

소규모펀드 임의해지 권유는 일부 성과가 있는 것으로 보인다. 한편 소규모펀드에서 펀드연령과 비용부담률은 중대형펀드의 경우보다 모두 유의하게 성과에서 더 부정적인 효과가 나타나고 있다. 그러므로 소규모펀드에 투자하는 경우 설정된 지 오래된 펀드는 투자 성과가 불리하게 나타나서 소외펀드화 되고 있음이 추정된다.

<표 4-1>의 중간부분은 총비용부담률(EXPRATIO) 변수 대신 비용을 구분하여, 판매보수율 (S. F. RATIO)과 운용보수율(Mgt. F. RATIO)을 통제변수로 각각 분석한 결과를 보여주고 있다. 전체기간에서 운용보수율은 시장조정 모형에서만 유의한 음(-)의 관계, 판매보수율은

〈표 5〉 전/후반기 소규모 및 중대형펀드 패널분석-판매보수, 운용보수

연구기간을 전, 후반기로 구분하여 소규모 및 중대형펀드 그룹의 각 펀드월(fund months) 표본에 대하여 위험조정 벤치마크 대비 초과수익률('FUNDRET')을 종속변수로 하여 패널분석한 결과임. 통제변수들의 계수는 생략하였으며, 변수의 정의등 기타 사항은 앞선 표의 설명과 동일함.

\begin{tabular}{|c|c|c|c|c|}
\hline Variables & $\begin{array}{c}(1) \\
\text { Market Adj. } \\
\text { Return }\end{array}$ & $\begin{array}{c}(2) \\
C A P M \text { Adj. } \\
\text { Return }\end{array}$ & $\begin{array}{c}\text { (3) } \\
\text { 4-Factor Adj. } \\
\text { Return }(V W)\end{array}$ & $\begin{array}{c}\text { (4) } \\
\text { 4-Factor Adj. } \\
\text { Return }(E W)\end{array}$ \\
\hline \multicolumn{5}{|l|}{ lag S. F. RATIO } \\
\hline 전반기 소규모 & $\begin{array}{l}-0.136^{* * *} \\
(-3.14)\end{array}$ & $\begin{array}{l}-0.145^{\text {*** }} \\
(-2.86)\end{array}$ & $\begin{array}{l}-0.147^{* * *} \\
(-2.90)\end{array}$ & $\begin{array}{l}-0.145^{* * *} \\
(-2.91)\end{array}$ \\
\hline 전반기 중대형 & $\begin{array}{l}-0.120^{* * *} \\
(-2.93)\end{array}$ & $\begin{array}{l}-0.128^{* * *} \\
(-3.25)\end{array}$ & $\begin{array}{l}-0.130^{* * *} \\
(-3.30)\end{array}$ & $\begin{array}{l}-0.130^{\text {*** }} \\
(-3.28)\end{array}$ \\
\hline 후반기 소규모 & $\begin{array}{l}-0.086^{* *} \\
(-2.27)\end{array}$ & $\begin{array}{l}-0.084^{*} \\
(-1.95)\end{array}$ & $\begin{array}{l}-0.083^{*} \\
(-1.93)\end{array}$ & $\begin{array}{l}-0.082^{*} \\
(-1.91)\end{array}$ \\
\hline 후반기 중대형 & $\begin{array}{l}-0.003 \\
(-0.09)\end{array}$ & $\begin{array}{l}-0.011 \\
(-0.28)\end{array}$ & $\begin{array}{l}-0.013 \\
(-0.33)\end{array}$ & $\begin{array}{l}-0.012 \\
(-0.29)\end{array}$ \\
\hline \multicolumn{5}{|l|}{ lag Mgt. F. RATIO } \\
\hline 전반기 소규모 & $\begin{array}{l}-0.247^{\text {*** }} \\
(-2.88)\end{array}$ & $\begin{array}{l}-0.184^{* *} \\
(-2.04)\end{array}$ & $\begin{array}{l}-0.195^{* *} \\
(-2.18)\end{array}$ & $\begin{array}{l}-0.196^{* *} \\
(-2.22)\end{array}$ \\
\hline 전반기 중대형 & $\begin{array}{r}0.086 \\
(1.30)\end{array}$ & $\begin{array}{l}0.173^{* *} \\
(2.48)\end{array}$ & $\begin{array}{l}0.170^{* *} \\
(2.40)\end{array}$ & $\begin{array}{l}0.168^{* *} \\
(2.39)\end{array}$ \\
\hline 후반기 소규모 & $\begin{array}{l}-0.067 \\
(-1.10)\end{array}$ & $\begin{array}{l}-0.078 \\
(-1.11)\end{array}$ & $\begin{array}{l}-0.077 \\
(-1.10)\end{array}$ & $\begin{array}{l}-0.082 \\
(-1.16)\end{array}$ \\
\hline 후반기 중대형 & $\begin{array}{l}-0.096 \\
(-1.46)\end{array}$ & $\begin{array}{l}-0.076 \\
(-1.09)\end{array}$ & $\begin{array}{l}-0.078 \\
(-1.12)\end{array}$ & $\begin{array}{l}-0.077 \\
(-1.11)\end{array}$ \\
\hline Monthly Fixed Effects & Yes & Yes & Yes & Yes \\
\hline Observations & $\begin{array}{r}4,744 \\
7,603 \\
12,665 \\
19,900 \\
\end{array}$ & $\begin{array}{r}4,744 \\
7,603 \\
12,665 \\
19,900 \\
\end{array}$ & $\begin{array}{r}4,744 \\
7,603 \\
12,665 \\
19,900 \\
\end{array}$ & $\begin{array}{r}4,744 \\
7,603 \\
12,665 \\
19,900\end{array}$ \\
\hline $\mathrm{R}$-squared & $\begin{array}{l}0.387 \\
0.190 \\
0.083 \\
0.055\end{array}$ & $\begin{array}{l}0.301 \\
0.526 \\
0.226 \\
0.275\end{array}$ & $\begin{array}{l}0.288 \\
0.490 \\
0.197 \\
0.245\end{array}$ & $\begin{array}{l}0.272 \\
0.492 \\
0.204 \\
0.243\end{array}$ \\
\hline
\end{tabular}


An Empirical Study on Size and Age Effects in Korean Equity Funds

모든 모형에서 매우 유의한 음(-)의 관계를 나타내고 있으며 기존연구인 Won and Hahn(2011)과 Cho and Shin(2012)의 연구결과와 대체로 일치하고 있다.

<표 5>에서 전반기에는 소규모펀드의 경우 판매보수율과 운용보수율 모두 펀드 성과와 음(-)의 유의한 관계였으나 후반기에는 판매보수율은 지속적으로 음(-)의 관계가 나타났지만 운용보수율은 음(-)의 관계가 유의하지 않았다. 이와는 대조적으로 중대형펀드의 경우에는 글로벌금융위기 이전에 판매보수율은 음(-)의 관계를 나타냈지만, 운용보수율은 양(+)의 관계를 나타내서 운용보수율이 높은 경우 펀드 성과가 좋은 것으로 나타났다. 그러나 위기 이후에는 두 변수 모두 유의하지 않게 나타났다.

결과적으로 금융위기 이전에 있어서 펀드 규모별로 운용보수가 펀드 성과에 미치는 영향은 차이가 나서, 소규모펀드에 대한 펀드매니저에 의한 소외현상이 존재하는 것으로 해석된다. 또한 금융위기 이후 기간에 판매보수율과 관련하여 소규모펀드에 대해서만 음(-)의 유의한 관계가 지속되고 있어 2009년 말을 전후해서 시작된 펀드비용 인하조치가 소규모펀드보다 중대형펀드에 유리하게 작용하였음을 추정하게 한다.

<표 4-1>에서 펀드패밀리 규모는 Ban and Choe(2013) 등을 비롯하여 기존연구에서 대체로 양 $(+)$ 의 효과를 가진다고 보고되었으나, 본 연구에서는 유의하지 않은 것으로 나타났다.

또, 현금보유 비중은 전체기간, 모든 모형에서 유의하지 않은 것으로 나타났다. 앞서 본 대로 Ban and Choe(2013)에서는 현금보유비중이 소규모펀드에서 상당 폭 크게 나타나며 회귀분석 결과 현금보유비중 변수가 위험조정 성과를 좌우하는 뚜렷한 변수라고 하였으나, 통계 요약표나 베타로 추정한 현금보유비중의 수준 및 회귀분석의 결과들을 미루어 보면 적어도 현금보유비중이 본 연구의 전체 분석대상 기간에서 의미 있는 변수는 아니라고 판단된다.

\section{2 규모효과의 선형관계 여부와 펀드의 최적규모}

\subsection{1 규모효과의 선형관계 여부}

Indro et al.(1999)의 방법론을 원용하여 펀드규모의 2차항을 포함시킨 패널분석을 수행한 결과, <표 6-1>에서 보는 바와 같이 2차항계수가 $1 \%$ 유의수준에서 음(-)의 값을 가진다. 이는 국내 주식형 펀드의 규모효과가 비선형성을 가짐을 암시한다. 즉, 국내 주식형 펀드의 규모가 커짐에 따라 어느 수준까지는 펀드성과에 유리하지만 그 수준을 넘어서면 오히려 성과가 감소함을 나타내고 있다.

\subsection{2 펀드의 최적규모}

규모효과의 비선형성에 덧붙여 앞서 연구모형에서 살펴 본 대로 펀드의 최적규모는 LOGTNA $=-\beta_{1} /\left(2 \beta_{2}\right)$ 로 계산되며 <표 6-2>는 그 결과로서 최적규모를 보여주고 있다. 시장조정 성과모형 에서는 약 257 억 원, CAPM 모형에서는 245억 원, 4 요인 모형에서는 39 60억 원으로 나타나 국내 펀드의 최적규모는 매우 낮은 수준이다. Indro et al.(1999)에서는 회귀식에 따라 약 9.46억 달러와 11억 달러 수준이며 국내 연구로서 Suh et al.(2008)은 2002년 1월부터 2007년 6월까지 주식형 펀드 분석에서 772억 원과 1,178억 원, 또한 Lee(2011)는 2006년부터 2010년 6월까지 주식형 펀드 자료를 대상으로 모형에 따라 1,091억 원과 251억 원이라고 분석하였다. 
한국증권학회지 제48권 6호 (2019)

〈표 6-1〉 규모효과의 비선형성 체크(펀드규모 이차항 포함)

이 표는 각 기간별 전체펀드 그룹의 각 펀드월(fund months) 표본에 대하여 위험조정 벤치마크 대비 초과수익률('FUNDRET')을 종속변수로 하여 패널분석한 결과임. 규모효과의 비선형성을 체크하기 위해 규모변수의 이차항인(LOGTNA)을 포함시켰음. 다만 이차항을 포함하면 규모효과의 유의성에 영향을 주므로 규모효과의 판단여부는 이차항을 포함하지 않은 <표 4-1>에서 이루어지고 여기서는 이차항의 부호가 유의하게 음수인지에만 초점을 맞춤. 변수의 정의등 기타 사항은 앞선 표의 설명과 동일함.

\begin{tabular}{ccccc}
\hline Variables & $(1)$ & $(2)$ & $(3)$ & $(4)$ \\
& $\begin{array}{c}\text { Market Adj. } \\
\text { Return }\end{array}$ & $\begin{array}{c}\text { CAPM Adj. } \\
\text { Return }\end{array}$ & $\begin{array}{c}\text { 4-Factor Adj. } \\
\text { Return }(\text { VW }\end{array}$ & $\begin{array}{c}\text { 4-Factor Adj. } \\
\text { Return }(E W)\end{array}$ \\
\hline 전체기간 & & & & \\
lag LOGTNA & $0.044^{* * *}$ & $0.043^{* * *}$ & $0.031^{* * *}$ & $0.021^{*}$ \\
lag LOGTNA & $(4.04)$ & $(3.59)$ & $(2.62)$ & $(1.76)$ \\
& $-0.004^{* * *}$ & $-0.004^{* * *}$ & $-0.004^{* * *}$ & $-0.003^{* *}$ \\
& $(-3.75)$ & $(-3.46)$ & $(-3.36)$ & $(-2.55)$ \\
\hline
\end{tabular}

〈표 6-2〉 펀드의 최적규모

펀드의 최적규모를 각 위험조정 벤치마크별로 구한 값을 보여주고 있다. 규모효과의 비선형성을 검증하기 위하여 규모변수의 이차항을 포함시키면 $F U N D R E T_{i, t}=\mu_{t}+\beta_{1} \times L O G T N A_{i, t-1}+\beta_{2} \times\left(L O G T N A_{i, t-1}\right)^{2}+$ $\gamma X_{i, t-1}+\epsilon_{i, t}$ 이를 패널분석하고 위 식을 규모변수(LOGTNA)에 대하여 1차 미분하면 LOGTNA $=-\beta_{1} /$ $\left(2 \beta_{2}\right)$. 이식에서 최적규모인 TNA를 구하게 됨. beta 1 , beta 2 는 각각 회귀식의 계수인 $\beta_{1}, \beta_{2}$ 를 나타냄. Market Adj. Return은 펀드의 수익률에서 시장수익률을 차감한 시장조정 수익률이며 CAPM Adj. Return은 CAPM을 사용한 조정수익률을, 4-Factor Adj. Ret(VW)은 Carhart(97) 방법론을 사용한 4요인 모형의 가치가중 조정수익률, 4-Factor Adj. Ret(EW)는 4요인모형의 동일가중 조정수익률을 나타냄.

\begin{tabular}{llccc}
\hline & \multicolumn{3}{c}{ 전체 기간(2006년 1월 2015년 12월) } \\
\cline { 2 - 5 } & beta 1 & beta 2 & LOG(TNA) & TNA(억원) \\
\hline Market Adj. Ret & $0.0444^{* * * *}$ & $-0.0040^{* * *}$ & 5.550 & 257.238 \\
CAPM Adj. Ret & $0.0429^{* * *}$ & $-0.0039^{* * *}$ & 5.500 & 244.692 \\
4-Factor Adj. Ret(VW) & $0.0311^{* * *}$ & $-0.0038^{* * *}$ & 4.092 & 59.866 \\
4-Factor Adj. Ret(EW) & $0.0205^{*}$ & $-0.0028^{* *}$ & 3.661 & 38.889 \\
\hline
\end{tabular}

이러한 국내 기존연구들의 분석기간은 대체로 본 연구의 전반기에 해당한다. 표는 생략하였지만 전반기만의 최적규모는 기존 연구들과 그다지 다르지 않았으나 후반기의 최적규모는 급격히 줄어들어 전체기간의 최적규모 값을 크게 낮추고 있음이 확인되었다. 즉, 전체기간에서 펀드 최적규모가 매우 낮아진 것은 후반기에 기인한 것이다. 앞서 국내 주식형 펀드 규모는 전반기보다 후반기에 다소 개선된 것으로 나타났는데, 펀드의 최적규모는 왜 오히려 훨씬 작아졌는지 의문시 된다. 이는 앞서 본 바와 같이 그동안 양(+)으로 알려져 왔던 국내 주식형펀드의 규모효과가 중대형펀드의 경우 후반기에 확연히 음(-)으로 반전된 것과 동일한 선상에서 이해될 수 있을 것이다. 즉, 펀드의 규모가 커지면서 규모의 경제가 작용하여 펀드성과에 유리하게 작용하지만, 규모가 어느 수준 이상 커지면 시장충격으로 인한 거래비용 증가 등 여러 불리한 점에 직면하게 되는데 후반기에는 이 현상이 국내 펀드에서 나타나고 있음을 보여주고 있다. 
An Empirical Study on Size and Age Effects in Korean Equity Funds

그 주된 이유는 후반기에 주식시장이 침체되면서 대형주 위주의 상승장이 아니라 일부 중소형주 혹은 성장주에 투자하는 펀드의 수익률이 우월한 경우가 많았고, 이런 유형의 펀드는 그 특성상 펀드규모가 그다지 크지 않기 때문일 것으로 추정된다.

\section{3 유동성가설의 검증}

$<$ 표 $7>$ 에서 펀드규모와 성장주 투자펀드의 상호작용항 변수의 계수 $\left(\phi_{3}\right)$ 는 전체펀드, 전체기간

〈표 7〉 유동성가설 검증-성장주 투자 펀드

전체기간에 대해 전체펀드와 소규모 및 중대형펀드그룹의 각 펀드월(fund months) 표본에 대하여 위험조정 벤치마크 대비 초과수익률('FUNDRET')을 종속변수로 하여 패널분석한 결과임. 유동성가설을 검증하기 위해 GROWTH DUMMY인 성장주 투자 펀드를 ' 1 '로 하는 더미변수를 추가하였고, LOGTNA $\times$ GR DUMMY는 규모변수와 성장주 펀드 더미변수와의 상호작용항 변수이며 성장주 펀드이기 때문에 추가로 야기되는 차별적인 규모효과를 나타낸다. 변수의 정의 및 기타사항은 다른 표에서와 동일함.

\begin{tabular}{|c|c|c|c|c|}
\hline Variables & $\begin{array}{c}(1) \\
\text { Market Adj. } \\
\text { Return }\end{array}$ & $\begin{array}{c}(2) \\
C A P M \text { Adj. } \\
\text { Return }\end{array}$ & $\begin{array}{c}\text { (3) } \\
\text { 4-Factor Adj. } \\
\text { Return }(V W)\end{array}$ & $\begin{array}{c}\text { (4) } \\
\text { 4-Factor Adj. } \\
\text { Return }(E W)\end{array}$ \\
\hline \multicolumn{5}{|l|}{ 전체 펀드 } \\
\hline lag LOGTNA & $\begin{array}{l}0.005 \\
(1.21)\end{array}$ & $\begin{array}{l}0.003 \\
(0.82)\end{array}$ & $\begin{array}{l}-0.008^{*} \\
(-1.96)\end{array}$ & $\begin{array}{l}-0.009^{* * *} \\
(-2.32)\end{array}$ \\
\hline GROWTH DUMMY & $\begin{array}{l}0.096 \\
(0.96)\end{array}$ & $\begin{array}{l}0.115 \\
(102)\end{array}$ & $\begin{array}{l}0.088 \\
(078)\end{array}$ & $\begin{array}{l}0.070 \\
(063)\end{array}$ \\
\hline lag LOGTNA×GR DUMMY & $\begin{array}{l}-0.032^{* *} \\
(-1.96) \\
\end{array}$ & $\begin{array}{r}-0.029 \\
(-1.59) \\
\end{array}$ & $\begin{array}{r}-0.022 \\
(-1.22) \\
\end{array}$ & $\begin{array}{r}-0.018 \\
(-1.00) \\
\end{array}$ \\
\hline \multicolumn{5}{|l|}{ 중대형펀드 (전반기) } \\
\hline lag LOGTNA & $\begin{array}{r}0.008 \\
(0.80)\end{array}$ & $\begin{array}{r}0.004 \\
(0.42)\end{array}$ & $\begin{array}{l}-0.006 \\
(-0.59)\end{array}$ & $\begin{array}{l}0.003 \\
(0.27)\end{array}$ \\
\hline GROWTH DUMMY & $\begin{array}{l}-0.471 \\
(-1.27)\end{array}$ & $\begin{array}{c}-0.587^{*} \\
(-1.69)\end{array}$ & $\begin{array}{c}-0.605^{*} \\
(-1.72)\end{array}$ & $\begin{array}{l}-0.561 \\
(-1.60)\end{array}$ \\
\hline lag LOGTNA $\times G R D U M M Y$ & $\begin{array}{l}-0.001 \\
(-0.02) \\
\end{array}$ & $\begin{array}{r}0.024 \\
(0.62) \\
\end{array}$ & $\begin{array}{r}0.026 \\
(0.65) \\
\end{array}$ & $\begin{array}{r}0.020 \\
(0.49) \\
\end{array}$ \\
\hline \multicolumn{5}{|l|}{ 중대형펀드 (후반기) } \\
\hline $\operatorname{lag}$ LOGTNA & $\begin{array}{l}-0.010 \\
(-1.26)\end{array}$ & $\begin{array}{l}-0.011 \\
(-1.34)\end{array}$ & $\begin{array}{l}-0.013 \\
(-1.54)\end{array}$ & $\begin{array}{l}-0.012 \\
(-1.48)\end{array}$ \\
\hline GROWTH DUMMY & $\begin{array}{l}0.619^{* * *} \\
(3.32)\end{array}$ & $\begin{array}{l}0.695^{\text {*** }} \\
(3.40)\end{array}$ & $\begin{array}{l}0.661^{\text {*** }} \\
(3.25)\end{array}$ & $\begin{array}{l}0.692^{* * *} \\
(3.39)\end{array}$ \\
\hline lag LOGTNA×GR DUMMY & $\begin{array}{l}-0.094^{* * *} \\
(-3.22)\end{array}$ & $\begin{array}{l}-0.102^{\text {*** }} \\
(-3.26)\end{array}$ & $\begin{array}{l}-0.096^{* * *} \\
(-3.09)\end{array}$ & $\begin{array}{l}-0.102^{* * *} \\
(-3.25)\end{array}$ \\
\hline Monthly Fixed Effects & Yes & Yes & Yes & Yes \\
\hline Observations & $\begin{array}{r}44,912 \\
7,546 \\
19,519 \\
\end{array}$ & $\begin{array}{r}44,912 \\
7,546 \\
19,519 \\
\end{array}$ & $\begin{array}{r}44,912 \\
7,546 \\
19,519 \\
\end{array}$ & $\begin{array}{r}44,912 \\
7,546 \\
19,519 \\
\end{array}$ \\
\hline R-squared & $\begin{array}{l}0.134 \\
0.190 \\
0.051\end{array}$ & $\begin{array}{l}0.322 \\
0.528 \\
0.278\end{array}$ & $\begin{array}{l}0.292 \\
0.491 \\
0.250\end{array}$ & $\begin{array}{l}0.292 \\
0.493 \\
0.248\end{array}$ \\
\hline
\end{tabular}


한국증권학회지 제48권 6호 (2019)

에서는 대체로 유의하지 않지만 유동성이 부각되는 중대형펀드의 경우는 후반기 매우 유의한 음(-)의 값을 보이고 있어, 펀드규모가 커짐에 따라 유동성문제로 인하여 성과에 부정적이라는 유동성가설이 후반기에는 지지됨이 확인되고 있다.6)

특징적인 것은 후반기에는 성장주펀드의 해당 더미변수의 회귀계수가 매우 유의하게 양(+)의 값을 나타내고 있다. 또, 표는 생략하였지만 앞서 본 제로인 자료상 표본수가 부족하였던 소형주 투자펀드에 중형주 투자펀드를 합하여 중소형주 투자펀드로 분석한 결과 역시 더미변수의 회귀계수가 매우 유의하게 양(+)이었다. 이것은 분석기간 동안 성장주나 중소형주에 투자하는 펀드의 수익률이 우월했음을 보여 주고 있다. 즉, 펀드규모가 너무 커지면 유동성이 문제되는 펀드의 경우 성과에 불리하게 작용하지만 적정규모까지는 오히려 성장주나 중소형주 투자펀드들의 수익률이 양호하였다. 이는 앞서 본 펀드의 최적규모가 후반기 크게 낮아진 점을 일부 설명할 수 있는 것으로 보인다.

결국, 금융위기 이후 주식시장 침체기에 있어서 국내 유동성가설은 지지되고 있으며, 따라서 이러한 펀드에 투자하는 경우 규모가 크지 않은 펀드를 선택하는 것이 바람직함을 시사하고 있다.

\section{4 펀드의 연령효과와 소외펀드}

펀드 규모, 연령 및 비용부담률(EXPRATIO)의 세 가지 변수의 상관관계(<표 2-2>)는 오래된 소규모펀드가 불리할 수 있음을 시사하고 있고 또한 앞서 <표 4-1>의 회귀분석 결과는 펀드의 연령이 매우 유의하게 펀드의 성과에 부정적임을 보여주었다. 연령효과를 더 자세히 분석하기 위해 펀드규모와 펀드연령의 상호작용항 변수를 넣어 분석한 결과, <표 8-1>에서 보는 바와 같이 전반기(2006.1 2009.12)의 경우 펀드연령이 펀드성과에 대해 부정적 영향을 미치고 있지만 펀드 연령과 규모의 상호작용항 회귀계수는 모든 모형에서 유의하게 양(+)으로 나타났다. 이는 오래된 펀드인데도 불구하고 그 규모가 큰 경우에는 성과에 유리하게, 반면 규모가 작고 오래된 펀드는 성과가 추가적으로 불리한 것을 나타내고 있다.7) 이에 따라 펀드연령이 오래되고 규모가 작은 펀드의 경우 소외펀드의 문제가 있음을 강하게 시사한다.

<표 8-2>는 펀드연령을 10 분위(decile)로 나누어 각 분위별로 펀드의 수, 평균규모와 자금흐름 및 위험조정 벤치마크 대비 수익률을 보여주고 있다. 우선 펀드수가 약 7년을 지나면서 줄어들고 있으며 9년 이상 된 펀드는 연수에 제한이 없는데도8) 1 년 기준인 각 분위 그룹의 펀드 수보다 작아서 우리나라 펀드의 대형화, 장기화는 전혀 이루어지고 있지 않음을 알 수 있다. 펀드 규모는 커지다가 5 6년 그룹에서 795억 원을 정점으로 줄어들기 시작하여 9년 이후 그룹에서는 425억

6) 최근 연구결과로서 Ban and Choe(2013)에서는 소형주펀드만을 대상으로 하여(39개 펀드: 표본 수는 알 수 없음), 분석결과 표는 생략하고 있지만 규모 하위 $40 \%$ 혹은 하위 $60 \%$ 를 제외한 펀드에서만 $10 \%$ 유의수준에서 상호작용항의 회귀계수가 음(-)으로 나왔다고 기술하고 있다.

7) 전체기간 및 후반기에는 상호작용항 변수의 계수가 유의하지 않게 나타나서 표를 생략한다.

8) 본 연구의 대상기간은 10 년이지만 설정일로 제한을 둔 것은 아니므로 자료상 펀드연령이 10 년 이상 된 펀드들도 포함되어 있다. 
An Empirical Study on Size and Age Effects in Korean Equity Funds

원으로 거의 절반 수준으로 바뀌고 있다. 펀드의 자금흐름은 2 3년 그룹에서부터 유출되기 시작하여 3 4년 그룹에서 유출이 본격화되며 그 속도는 7 8년 그룹까지 증가하게 되며 이를 정점으로 8년 이후는 유출속도가 조금씩 감소하고 있지만 소규모화 된 상태로 지속되는 것으로 추정된다. Park and Park(2011)은 7년을 넘어서게 되면 이런 상태가 되어 '사(死)펀드화'되어 간다고 표현하고 있는데 본 연구에서도 이와 크게 다르지 않은 펀드의 생애주기가 관찰되고 있다. 위험조정 벤치마크 대비 수익률을 보면 4 5년 그룹에서부터 의미 있는 성과 감소가 나타나기 시작한다.

〈표 8-1〉 펀드의 연령효과 분석(2006.1 2009.12)

연구기간 전반기 전체펀드 그룹의 총 12,347 개의 펀드월(fund months)표본에 대하여 각 위험조정 벤치마크 대비 초과수익률('FUNDRET')을 종속변수로 하여 패널분석한 결과임. 패널분석 시 각 시점의 시간고정 효과를 통제하였고 'lag' 표시는 종속변수보다 한 기간 이전(t-1) 시점의 독립변수들을 의미함. TNA는 펀드의 순자산이며 $\mathrm{AGE}$ 는 펀드의 연령, LOGTNA $\times \mathrm{Age}$ 는 펀드규모와 연령변수의 상호작용항 변수임. FAMSIZE는 해당 펀드가 속한 패밀리의 총순자산에서 해당 펀드의 순자산을 차감한 값임. EXPRATIO는 펀드의 명시적 총비용을 순자산으로 나눈 값이며 판매수수료를 연할하여 포함하고 있다. FLOW는 해당 펀드의 최근 한 달간의 자금흐름이며 CASH RATIO는 현금 및 현금등가물을 순자산으로 나눈 값임. PAST RETURN은 최근 12 개월간의 누적수익률을 의미함. Market Adj. Return은 시장조정 수익률이며 CAPM Adj. Return은 CAPM을 사용한 조정수익률을, 4-Factor Adj. Return(VW)과 4-Factor Adj. Return (EW)은 각각 Carhart(97) 방법론을 사용한 4요인 모형의 가치가중, 동일가중 조정수익률을 의미한다. 'LOG'는 자연로그를 취한 값이며 괄호 안의 수치는 유의수준을 나타내는 통계량 ' $\mathrm{t}$ '값이다.

\begin{tabular}{|c|c|c|c|c|}
\hline Variables & $\begin{array}{c}\text { (1) } \\
\text { Market } \\
\text { Adj. Return }\end{array}$ & $\begin{array}{c}(2) \\
\text { CAPM } \\
\text { Adj. Return }\end{array}$ & $\begin{array}{c}\text { (3) } \\
\text { 4-Factor } \\
\text { Adj. Return } \\
\text { (VW) }\end{array}$ & $\begin{array}{c}\text { (4) } \\
\text { 4-Factor } \\
\text { Adj. Return } \\
\text { (EW) }\end{array}$ \\
\hline lag LOGTNA & $\begin{array}{l}-0.004 \\
(-0.31)\end{array}$ & $\begin{array}{l}0.001 \\
(0.06)\end{array}$ & $\begin{array}{l}-0.017 \\
(-1.21)\end{array}$ & $\begin{array}{l}-0.014 \\
(-1.03)\end{array}$ \\
\hline lag Age & $\begin{array}{l}-0.048^{* * *} \\
(-3.52)\end{array}$ & $\begin{array}{l}-0.035^{* *} \\
(-2.44)\end{array}$ & $\begin{array}{l}-0.035^{* *} \\
(-2.45)\end{array}$ & $\begin{array}{l}-0.034^{* *} \\
(-2.40)\end{array}$ \\
\hline lag LOGTNA $\times$ Age & $\begin{array}{l}0.007^{* * *} \\
(2.70)\end{array}$ & $\begin{array}{l}0.006^{* *} \\
(2.07)\end{array}$ & $\begin{array}{l}0.005^{* *} \\
(2.05)\end{array}$ & $\begin{array}{l}0.005^{*} \\
(1.80)\end{array}$ \\
\hline lag LOGFAMSIZE & $\begin{array}{r}0.021 \\
(1.44)\end{array}$ & $\begin{array}{c}0.002 \\
(0.15)\end{array}$ & $\begin{array}{l}0.006 \\
(0.42)\end{array}$ & $\begin{array}{l}0.006 \\
(0.47)\end{array}$ \\
\hline lag EXPRATIO & $\begin{array}{l}-0.122^{* * *} \\
(-4.37)\end{array}$ & $\begin{array}{l}-0.115^{* * *} \\
(-3.89)\end{array}$ & $\begin{array}{l}-0.110^{* * *} \\
(-3.75)\end{array}$ & $\begin{array}{l}-0.109^{* * * *} \\
(-3.78)\end{array}$ \\
\hline lag_FLOW & $\begin{array}{l}-0.001 \\
(-0.31)\end{array}$ & $\begin{array}{l}-0.001 \\
(-0.43)\end{array}$ & $\begin{array}{l}-0.002 \\
(-0.61)\end{array}$ & $\begin{array}{l}-0.001 \\
(-0.57)\end{array}$ \\
\hline lag_CASH RATIO & $\begin{array}{r}0.010 * * \\
(2.56)\end{array}$ & $\begin{array}{r}0.001 \\
(0.29)\end{array}$ & $\begin{array}{l}-0.000 \\
(-0.06)\end{array}$ & $\begin{array}{l}-0.001 \\
(-0.23)\end{array}$ \\
\hline Past Return & $\begin{array}{l}-0.001 \\
(-0.35)\end{array}$ & $\begin{array}{l}-0.001 \\
(-0.24)\end{array}$ & $\begin{array}{l}-0.001 \\
(-0.40)\end{array}$ & $\begin{array}{l}-0.001 \\
(-0.22)\end{array}$ \\
\hline Month Fixed Effects & Yes & Yes & Yes & Yes \\
\hline Observations & 12,347 & 12,347 & 12,347 & 12,347 \\
\hline Adjusted R-squared & 0.248 & 0.421 & 0.394 & 0.393 \\
\hline
\end{tabular}


한국증권학회지 제48권 6호 (2019)

〈표 8-2〉 펀드의 연령별 특성 추이

53,298 개의 펀드월(fund months) 표본을 대상으로 연령을 기준으로 10 분위(decile)로 나누어 분석한 결과이다. 펀드 연령은 펀드 설정일로부터의 펀드월 시점까지의 경과 기간이며 펀드 수는 표본 펀드 중 펀드 연령이 각 분위에 속하는 펀드의 수를 의미한다. 펀드규모는 증시의 호불황에 의한 영향을 배제하기 위해 순자산(TNA)이 아닌 펀드 설정액을 기준으로 하였다. 펀드 평균 자금흐름과 초과수익률은 월별기준 이다. CAPM Alpha는 CAPM 성과지표 대비 초과수익률을, 4-Factor VW-Alpha 와 4-Factor EW-Alpha 는 Carhart(97) 방법론을 사용한 가치가중, 동일가중 4요인 모형의 성과지표 대비 초과수익률들을 의미한다. 마지막 분위인 10 분위는 펀드연령이 9 년 이상 된 모든 펀드를 대상으로 하였다. 대괄호 안의 수치는 표준편차임.

\begin{tabular}{lrrrrrrrrrr}
\hline \multicolumn{1}{c}{ 구분 } & 1년 미만 & 1 2년 & $2 \sim 3$ 년 & $3 \sim 4$ 년 & $4 \sim 5$ 년 & $5 \sim 6$ 년 & $6 \sim 7$ 년 & $7 \sim 8$ 년 & 8 9년 & 9년 이상 \\
\hline 펀드 수 & 534 & 532 & 479 & 478 & 461 & 412 & 622 & 529 & 361 & 292 \\
펀드규모 & 292.45 & 426.63 & 592.64 & 659.11 & 711.73 & 795.06 & 554.68 & 466.84 & 525.93 & 424.91 \\
(설정 액: 억 원) & {$[895]$} & {$[1,261]$} & {$[1,628]$} & {$[1,757]$} & {$[1,839]$} & {$[1,909]$} & {$[1,541]$} & {$[1,368]$} & {$[1,406]$} & {$[1,206]$} \\
펀드평균자금흐름(\%) & 3.545 & 1.371 & -0.381 & -1.549 & -1.826 & -1.950 & -2.155 & -2.250 & -1.648 & -1.671 \\
& {$[15.500]$} & {$[12.471]$} & {$[10.350]$} & {$[9.776]$} & {$[8.764]$} & {$[8.647]$} & {$[7.339]$} & {$[8.228]$} & {$[6.261]$} & {$[6.013]$} \\
CAPM Alpha(\%) & 0.118 & 0.165 & 0.072 & 0.126 & -0.015 & 0.004 & -0.068 & 0.038 & 0.067 & 0.024 \\
& {$[2.209]$} & {$[2.186]$} & {$[2.004]$} & {$[1.975]$} & {$[1.858]$} & {$[1.787]$} & {$[1.630]$} & {$[1.720]$} & {$[2.008]$} & {$[1.745]$} \\
4-Factor & -0.058 & -0.022 & -0.142 & -0.060 & -0.183 & -0.178 & -0.189 & -0.119 & -0.102 & -0.117 \\
VW-Alpha(\%) & {$[2.172]$} & {$[2.150]$} & {$[1.952]$} & {$[1.945]$} & {$[1.814]$} & {$[1.746]$} & {$[1.606]$} & {$[1.715]$} & {$[1.938]$} & {$[1.722]$} \\
4-Factor EW-Alpha & -0.050 & -0.002 & -0.126 & -0.045 & -0.171 & -0.165 & -0.188 & -0.106 & -0.103 & -0.108 \\
$\quad$ (\%) & {$[2.171]$} & {$[2.151]$} & {$[1.953]$} & {$[1.948]$} & {$[1.816]$} & {$[1.750]$} & {$[1.599]$} & {$[1.708]$} & {$[1.917]$} & {$[1.707]$} \\
Observations & 3,483 & 5,817 & 5,376 & 5,168 & 4,903 & 4,235 & 5,456 & 5,435 & 3,810 & 9,615 \\
\hline
\end{tabular}

이상을 종합하여 보면 펀드연령 4년부터 6년 사이에 펀드 규모나 자금흐름 그리고 펀드의 위험조정성과에서 상당한 변화가 있음을 알 수 있다. 또 통계 요약표상의 펀드 규모, 연령, 비용 부담률과의 관계, 그리고 펀드성과를 종속변수로 하는 회귀분석 결과에서 펀드연령 회귀계수가 모든 기준에서 일관되게 음(-)인 것과 소규모 펀드 그룹(Q1, Q2)에서 규모효과가 강하게 양 $(+)$ 의 회귀계수를 가져 규모의 경제가 작용하는 점, 그리고 소규모 펀드 그룹의 연령 및 비용부담률 회귀계수가 일반 펀드 그룹보다 더 불리해지는 점, 연구기간 전반기에 펀드규모와 연령의 상호작용항 회귀계수가 양(+)의 값을 가지는 점 등을 미루어 보면 소규모 펀드이면서 최소 $4 \sim 6$ 년 이상 된 오래된 펀드 그룹은 성과에서 더 불리해짐을 알 수 있다.

결국 오래된 소규모 펀드는 소외된다는 경험에서 환매를 권유하는 펀드 관련 업계의 관행은 일단 타당한 것으로 분석된다. 소규모펀드는 본 논문의 정의상 펀드 수로 전체표본의 약 $40 \%$ 에 해당하는 규모 분위그룹 Q1과 Q2를 의미하며, <표 2-1> 통계 요약표상의 Q2의 평균 순자산과 표준편차를 고려하면 소외펀드의 규모조건은 약 30 억 원 미만이나 40 억 원 미만의 펀드로 추정할 수 있다. 이 규모조건을 자로 잰 듯이 정확히 산출하는 것은 오히려 무의미하므로, 금융당국이 임의해지를 독려한 50억 미만의 펀드인 소위 자투리펀드로 까지 확대하여도 무리가 없을 것이다. 결국 소외펀드는 그 규모가 50억 원 미만이면서 펀드연령이 최소 $4 \sim 6$ 년 이상 된 펀드라고 정의할 수 있다. 단기화, 소형화되어 있는 한국 주식형 펀드의 특성을 고려하여 성과에서 불리해지기 쉬운 소외펀드의 실체를 펀드의 규모와 연령의 관점에서 실증 분석한 것은 본 연구의 의의라고 할 수 있다. 
An Empirical Study on Size and Age Effects in Korean Equity Funds

\section{5 소외펀드의 개선방안}

소외펀드가 발생하는 이유와 개선방안은 동전의 양면과 같으며 소외펀드의 문제 해결은 국내 펀드 수명의 장기화, 규모의 대형화를 위해서도 반드시 이루어져야 할 것이다.

첫째, 실제 운용업계에서는 소규모펀드는 주로 주니어 펀드매니저가 담당하고 있다. 그 가장 큰 이유는 소규모펀드에서의 자금 유출입은 자산배분이나 포트폴리오 비중을 중대형펀드보다 상대적으로 크게 변화시키기 때문에 펀드매니저 입장에서는 자신이 추종하여야 하는 모델 포트폴리오9)와의 괴리가 빈번할 수 있다는 우려감이 존재한다. 이점은 운용사와 투자자 사이의 대리인 비용으로 설명할 수 있을 것이다. 만약 펀드매니저 평가 시에 방법은 다양하겠지만 이를 고려하여 준다면10) 소규모펀드가 주니어 매니저에게만 배정되지는 않을 것이다. 다만 자산 운용사 입장에서는 굳이 그렇게 할 유인이 작으므로 이 점은 투자자의 지속적인 모니터링이나 금융당국의 개선조치가 있어야 할 것이다.

둘째, 소규모펀드를 장기간 보유한 투자자는 동 펀드의 투자자가 줄어들수록 앞서 환매한 투자자의 거래비용까지 누적적으로 부담하게 된다. 펀드 규모가 클 때에는 문제가 되지 않던 환매자금 마련을 위한 매매비용은, 펀드보유자 수가 줄어들수록 그 부담율이 높아지며 더구나 환매가 이루어질 때마다 남은 보유자는 누적적으로 이를 부담하게 된다. 그리고 단순한 매매비용 뿐만 아니라 매매 스프레드에서 오는 암묵적 비용을 고려하면 소규모펀드의 거래비용은 상당하다. Carhart(1997)는 펀드의 장기 보유자가 부담하게 되는 펀드자금 유출입으로 인한 거래비용을 지적하면서, 유동성이 낮은 주식들에 투자하는 펀드의 경우에는 장기 보유자를 보호하기 위해 펀드의 자금 유출입 시에 수반되는 거래비용을 따로 부과하는 경우가 미국에서 늘어나고 있다고 주장한다. 환매의 경우 국내 소규모펀드에서도 이를 참고할 수 있을 것으로 사료된다.

셋째, 펀드관련 기관들이 너무 쉽게 새로운 펀드를 설정하고 판매를 독려하는 업계의 관행도 소외펀드의 양산을 가져왔다. 정책당국에서는 가이드라인을 통하여 동일한 스타일의 펀드가 너무 많이, 쉽게 새로운 펀드인 것처럼 설립되어 투자자를 호도하는 현상에 제동을 걸 필요가 있다. 이런 분위기에 편승하여 자금력 있는 대형사의 경우는 펀드랭킹 상위에 자신들의 펀드를 포진시키기 위해 펀드 인큐베이션을 할 가능성도 있다. Evans(2010)가 지적한 대로 펀드의 인큐베이션 자체가 인큐베이션 이후 기간에서는 그 효과가 사라지는 단기적인 수익률 띄우기로 볼 수밖에 없는데 이 현상이 국내 펀드의 수명 단기화, 소형화의 원인이 될 수 있음을 주목해야 할 것이다.

넷째, 펀드 성과와 펀드 연령 간의 음(-)의 관계, 신생펀드의 성과 띄우기에 집중하는 국내 펀드업계의 관행은, 기본적으로 펀드 성과와 펀드의 자금 유출입이 비대칭적인 반응을 보인다는

9) 자산 운용사에서는 보통 자산운용회의에서 모델 포트폴리오를 정하고 펀드 매니저별로 여기에 약간의 재량을 부여하고 있는데 펀드매니저 입장에서는 이를 따르지 않았을 때의 비난이 칭찬보다 훨씬 크기 때문에 대부분 이를 추종해야 하는 부담이 있다.

10) 환매에 대비하여 현금보유 비중을 다소 높게 가져갔다거나 모델 포트폴리오와의 일시적인 괴리가 있어도, 이를 완화하여 매니저가 소홀히 하지 않았음이 인정되면 평가에서 불리하지 않도록 할 수 있을 것이다. 
한국증권학회지 제48권 6호 (2019)

펀드 소비자 행태의 볼록한 모양(convex shape) 이론과 관련되어 있다. Sirri and Tufano (1998)도 펀드는 단지 개별적인 개체가 아니라 그 펀드가 속한 전체 패밀리와 밀접한 관련이 있다고 하였으며 Nanda et al.(2004)은 이 볼록한 모양을 콜옵션의 그래프와 유사하다고 하였고 따라서 펀드회사 또는 펀드 패밀리는 스타펀드(star performer)가 가져오는 자금유입이라는 파급효과(spillover effect)에 끌리게 된다고 분석하고 있다. 국내에서의 신생펀드의 단기성과 지상주의는 이러한 소비자 행태의 비대칭적인 반응을 펀드 패밀리들이 이용하면서 수탁고라는 외형경쟁을 하고 있기 때문이기도 하다. 결국 소외펀드 및 펀드의 소형화, 단기화 현상이나 펀드 인큐베이션 문제도 이러한 펀드 패밀리의 이익을 위한 수탁고 경쟁과 무관하지 않을 것이다. 이에 따라 펀드 평가사와 매스컴은 펀드 랭킹이나 자산운용사 순위를 평가할 때 투자자들에게 올바른 정보를 주기 위해 이러한 점들을 고려하고 개선하여야 할 것이다. 이와 관련하여 Chevalier and Ellison(1997)은 높은 수익률을 원하는 투자자와 펀드패밀리 전체로의 자금흐름을 중시하는 펀드회사간의 대리인비용을 검증한 결과 일반펀드의 자금흐름과 성과간의 관계(flow-performance relationship)를 기관투자가만의 투자자로 구성된 펀드상품의 그것과 비교해 보면 시사점이 있을 것이라고 주장하였다. 외국에 비하여 펀드가 단기화, 소형화 되어 소외펀드가 양산되기 쉬운 국내의 현실을 고려하면 이런 대리인비용을 완화시킬 기관투자가의 역할을 부분적으로 대신할 시스템 보완이 요청된다.

다섯째, 본 연구에서 운용보수는 금융위기 이전 중대형펀드의 성과에 유의한 양(+)의 관계를 보이고 있으나, 판매보수는 성과와 일관되게 유의한 음(-)의 관계를 보이고 있다. 즉, 투자자가 판매기관에 매년 판매보수를 지불하고 그 대가로 받는 서비스는 투자자가 지불하는 비용을 커버하지 못함을 보여주고 있다. <표 2-1> 기초통계량에서 본 바와 같이 판매보수가 운용 보수보다 상당 폭 높게 책정되고 있음이 현실인데, 이것은 판매수수료가 일반화되어 있지 않아 판매보수가 이를 대신하는 의미를 가지고 있기 때문이지만 우리나라에 독특한 제도임은 앞서 본 대로이다. 이러한 이유에 더하여 이것은 판매기관과 운용사가 실질적인 계열관계에 있는 경우가 많기 때문에 파워게임에서 판매기관이 우월한 지위를 가지기 때문이기도 하다. 국내의 독특한 판매보수 제도는 역혁적인 이유 때문에 존재하게 되었는데 이제 그런 이유가 사라졌으므로 판매보수를 낮추어 최소한 운용보수가 판매보수보다는 높아야 할 것이다. 운용사는 펀드를 지속적으로 운용하기 때문에 운용보수가 높은 것은 펀드성과에 대한 유인이 될 수 있다. 그러나 판매보수는 일회성의 서비스에 대한 대가이므로 매년 수취하는 것은 문제가 있다. 다만, 판매보수를 낮추는 대신 펀드 판매사에게는 일회성의 판매수수료를 일반화, 현실화시켜 주는 것이 판매사의 입장에서도 본연의 역할이 강조되어 더 바람직하다. 클래스펀드 제도가 있긴 하지만 판매수수료가 그다지 높지 않고 따라서 매년 받는 판매보수가 아직도 높으며 더 근본적으로는 이는 선택사항이기 때문에 한계가 있다. 매년 수취하는 높은 판매보수라는 독특한 제도 때문에 펀드의 단기화 현상이 심화되고 그로 인해 펀드가 대형화되지 못하는 악순환이 거듭됨은 개선되어야 할 국내 펀드업계의 문제이다. 즉, 우리나라의 경우는 외국과 달리 판매수수료가 일반화되어 있지 않거나 낮으며 매년 부담하는 판매보수는 높으므로 투자자의 관점에서는 장기보유에 대한 이점이 없다. 만약 판매수수료를 현실화 시키고 대신 매년 고정적으로 
An Empirical Study on Size and Age Effects in Korean Equity Funds

받는 판매보수를 낮추면 펀드의 장기보유의 바탕이 마련되며 펀드회사들도 지금처럼 새로운 펀드를 대량 양산하면서 갈아타기를 권유하기가 어려워질 것이다. 현재의 국내 펀드 산업은 쉽게 펀드를 설정한 후 또한 쉽게 환매할 수 있게 되며, 운용사의 운용보수는 상대적으로 낮다. 특히 소규모 펀드가 일반 펀드보다 판매보수는 높고 운용보수가 낮음으로 인하여, 오래된 소규모의 펀드는 운용의 우선순위에서 밀릴 수밖에 없어 소외펀드가 지속적으로 양산되기 쉬운 구조이다. 국내 펀드의 장기화, 대형화를 위해서는 이러한 관점에서 펀드비용 전반에 대한 개선이 함께 이루어져야 할 것이다.

\section{5. 요약 및 결론}

본 연구에서 펀드의 위험조정 성과를 종속변수로 하고 펀드 규모와 연령 및 기타 주요변수들을 설명 및 통제변수로 한 패널분석의 결과, 그동안 알려져 왔던 양(+)의 규모효과는 사라졌고 펀드연령과 비용은 펀드성과에 부정적으로 나타났으며 특히 펀드비용의 경우는 운용보수와는 달리 판매보수가 성과에 부정적인 요인이었다.

글로벌금융위기를 지난 후반기에서 가장 특징적인 점은 중대형펀드에서 음(-)의 규모효과가 확연히 나타나고 있다는 것이다. 이러한 규모효과의 반전은 펀드규모와 성과 간의 비선형 관계를 시사하고 있어 규모변수의 이차항을 포함하여 분석한 결과 비선형성이 검증되었고 펀드의 최적규모는 이전 연구결과들에 비하여 크게 낮아졌다.

금융위기 이후 주식시장 침체기에 있어서는 성장주에 투자하는 펀드의 경우 유동성가설이 지지되는 것으로 나타났으며 펀드의 현금보유 비중이 펀드성과에 미치는 영향은 일부 기존 연구와는 달리 유의성이 없었다.

펀드비용과 연령의 경우 펀드성과에 일관되게 부정적이었지만 연구기간 후반기에는 다소 개선된 것으로 나타나 2009년 말을 전후한 금융당국의 보수인하 조치나 자투리펀드 해지권유 정책 등이 영향을 미친 것으로 추정되지만 소규모펀드의 불리함은 여전히 지속되고 있음이 확인되었다.

펀드규모와 연령의 상호작용항을 이용한 연령효과 분석에서는 오래된 펀드인데도 불구하고 그 규모가 큰 경우에는 성과에 유리하게 작용하였고 오래되었고 소규모펀드일 때는 추가로 불리하게 작용하였다. 이와 함께 펀드생애주기 분석의 결과 소외펀드는 50 억 원 미만의 펀드규모를 가지고 설정 후 4 6년 이상 된 펀드로 정의되었다. 본 연구는 펀드 관련 업계에서 막연히 성과 면에서 불리할 것이라고 알려져 왔던 소외펀드의 실체를 펀드규모와 연령의 관점에서 더 정확히 분석하였다는 데 그 의의가 있다.

외국의 경우 펀드가 오래되면 대형화되고 비용부담률이 낮아지는 반면 우리나라는 펀드가 오래되면 소형화되고 비용부담률은 높아지는데 이 현상은 반드시 시정되어야 한다. 결국 본 연구는 국내 주식형 펀드시장이 많은 펀드의 난립, 소규모화 이외에 펀드 연령에 따른 불리한 성과 및 높은 펀드비용 등을 조속히 시정할 필요성을 시사하고 있다. '자투리펀드'로 불리는 50 억 원 미만의 소규모펀드의 임의 해지를 독려하는 정책은 더욱 낮아진 최적규모로 인한 한국 
한국증권학회지 제48권 6호 (2019)

주식형 펀드시장의 소형, 단기화 현상과 오래된 소규모펀드가 소외되는 펀드의 연령이 주는 영향을 동시에 고려하여야 할 것이다. 좀 더 근본적으로는 기존 펀드의 장기화를 유도하기 보다는 외형경쟁을 위해 너무 손쉽게 새로운 펀드를 설정하고 판매를 독려하는 펀드업계의 관행도 지양되어야 할 것이다. 이와 함께 판매수수료나 판매보수, 펀드비용 문제와 환매제도 등의 개선을 통하여 신뢰받는 펀드들의 장기화, 대형화의 환경을 제도적 측면에서 조성할 것이 요청된다.

본 연구의 후반기에서는 주식시장 상황의 변화 및 주식형 펀드 산업의 많은 조치와 그에 상응하는 변화들이 나타나고 있다. 특히 후반기에서 나타난 규모효과의 음(-)으로의 반전과 펀드 최적규모의 급격한 감소는 유동성가설만으로 설명되기에는 부족하며, 향후 이에 대한 추가 연구가 요구된다. 또한 클래스펀드 등 다양한 펀드비용체계를 가진 펀드의 출현이 확대되고 있기 때문에, 이러한 펀드들의 투자성과에 대한 보다 정확한 분석도 이루어져야 할 것이다. 그리고 국내 펀드의 다량화, 단기화 및 소형화 현상과 일부 연관되어 있다고 추정되는 펀드의 인큐베이션 문제나 펀드 관련회사와 투자자와의 대리인비용 문제도 향후 연구의 대상이라 할 수 있다. 
An Empirical Study on Size and Age Effects in Korean Equity Funds

\section{References}

Ban, J., and H. Choe, 2011, "Zaturi" Funds and Agent Conflicts, Korean Finance Association Annual Conference Proceedings, pp. 1063-1092.

Ban, J., and H. Choe, 2013, Fund Size and Performance in a Market Crowded with Many Small Funds, Asia-Pacific Journal of Financial Studies, Vol. 42 (2), pp. 340-372.

Carhart, M. M., 1997, On Persistence in Mutual Fund Performance, The Journal of Finance, Vol. 52 (1), pp. 57-82.

Chan, H. W., R. W. Faff, D. R. Gallagher, and A. Looi, 2009, Fund Size, Transaction Costs and Performance: Size Matters! Australian Journal of Management, Vol. 34 (1), pp. 73-96.

Chen, J., H. Hong, M. Huang, and J. D. Kubik, 2004, Does Fund Size Erode Mutual Fund Performance? The Role of Liquidity and Organization, The American Economic Review, Vol. 94 (5), pp. 1276-1302.

Chevalier, J., and G. Ellison, 1997, Risk Taking by Mutual Funds as a Response to Incentives, Journal of Political Economy, Vol. 105 (6), pp. 1167-1200.

Cho, S. B., 2011, Strategic Cross-Fund Subsidization: Evidence from Equity Funds in Korea, KDI Journal of Economic Policy, Vol. 33 (1), pp. 45-72.

Cho, S., and I. Shin, 2012, Effects of Fund Sales Fees on Fund Flows and Fund Performance, Journal of Money \& Finance, Vol. 26 (1), pp. 78-108.

Edelen, R. M., R. B. Evans, and G. B. Kadlec, 2007, Scale Effects in Mutual Fund Performance: The Role of Trading Costs, Available at SSRN 951367.

Elton, E. J., M. J. Gruber, and C. R. Blake, 2001, A First Look at the Accuracy of the CRSP Mutual Fund Database and a Comparison of the CRSP and Morningstar Mutual Fund Databases, The Journal of Finance, Vol. 56 (6), pp. 2415-2430.

Evans, R. B., 2010, Mutual Fund Incubation, The Journal of Finance, Vol. 65 (4), pp. 1581-1611.

Fama, E. F., and J. D. MacBeth, 1973, Risk, Return, and Equilibrium: Empirical Tests, The Journal of Political Economy, Vol. 81 (3), pp. 607-636.

Fama, E. F., and K. R. French, 1993, Common Risk Factors in the Returns on Stocks and Bonds, Journal of Financial Economics, Vol. 33 (1), pp. 3-56.

Gaspar, J., M. Massa, and P. Matos, 2006, Favoritism in Mutual Fund Families? Evidence on Strategic Cross-Fund Subsidization, The Journal of Finance, Vol. 61 (1), pp. 73-104.

Indro, D. C., C. X. Jiang, M. Y. Hu, and W. Y. Lee, 1999, Mutual Fund Performance: Does Fund Size Matter? Financial Analysts Journal, Vol. 55 (3), pp. 74-87.

Jegadeesh, N., and S. Titman, 1993, Returns to Buying Winners and Selling Losers: Implications for Stock Market Efficiency, The Journal of Finance, Vol. 48 (1), pp. 65-91. 
한국증권학회지 제48권 6호 (2019)

Jones, M., 2007, Examination of Fund Age and Size and Its Impact on Hedge Fund Performance, Derivatives use, Trading \& Regulation, Vol. 12 (4), pp. 342-350.

Joo, S. H., H. C. Choi, and Y. A. Sung, 2009, Mutual Fund Investment by Individual Investors in Korea, Financial Planning Review, Vol. 2 (1), pp. 75-102.

Kang, J. K., and C. J. Lee, 2010, Investment Styles and Performance Persistence of Equity Funds in Korea Using Sharpe's Style Analysis, Korean Journal of Financial Studies, Vol. 39 (2), pp. 307-339.

Kim, T., and Y. Byun, 2011, The Relationship between Idiosyncratic Volatility and Expected Returns in the Korea Stock Market, Korean Journal of Financial Studies, Vol. 40 (3), pp. 525-550.

Ko, K. S., 2014, The Effects of Management and Sales Fees on Equity Fund Returns, The Korean Journal of Financial Management, Vol. 31 (4), pp. 129-150.

Lee, J. Y., 2011, A Study on the Optimal Size of Equity Funds in Korea, A doctoral dissertation at Catholic University of Korea.

Lee, M. Y., 2008, A Study on the Size Effect of Fund and Factors for Low Performance of Large Funds, A doctoral dissertation at Kyungwon University.

Morey, M. R., 2000, Mutual Fund Age and Morningstar Ratings, Financial Analysts Journal, Vol. 58 (2), pp. 56-63.

Morey, M. R., 2003, Should You Carry the Load? A Comprehensive Analysis of Load and No-Load Mutual Fund Out-of-Sample Performance, Journal of Banking \& Finance, Vol. 27 (7), pp. 1245-1271.

Nanda, V., Z. J. Wang, and L. Zheng, 2004, Family Values and the Star Phenomenon: Strategies of Mutual Fund Families, Review of Financial Studies, Vol. 17 (3), 667-698.

Park, K. H., and Y. S. Park, 2011, A Study on the Performance Management Bias of Korea Asset Management Companies, Korean Management Review, Vol. 40 (1), pp. 65-95.

Park, Y. K., 2005, A Study on the Behavior of Fund Investors and Fund Managers, Asian Review of Financial Research, Vol. 18 (1), pp. 31-67.

Sirri, E. R., and P. Tufano, 1998, Costly Search and Mutual Fund Flows, The Journal of Finance, Vol. 53 (5), pp. 1589-1622.

Suh, B. D., D. H. Hong, and M. Y. Lee, 2008, A Study on the Relationship of Fund Size and Performance : Does There Exist an Optimal Fund Size? Korean Journal of Business Administration, Vol. 21, pp. 323-345.

Won, S. Y., and S. B. Hahn, 2011, Fund Performance and Transaction Cost, Journal of Korean Economic Analysis, Vol. 17 (2), pp. 179-224.

Yan, X. S., 2008, Liquidity, Investment Style, and the Relation between Fund Size and Fund Performance, Journal of Financial and Quantitative Analysis, Vol. 43 (03), pp. 741-767. 